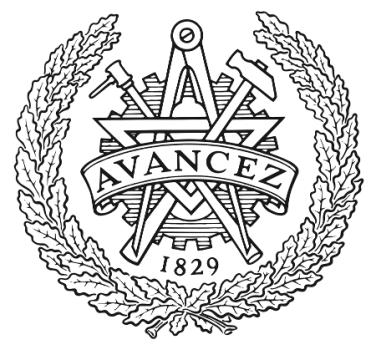

CHALMERS

UNIVERSITY OF TECHNOLOGY

\title{
The value creation of diffusion intermediaries: Brokering mechanisms and trade-offs in solar and wind power in Sweden
}

Downloaded from: https://research.chalmers.se, 2023-04-26 12:48 UTC

Citation for the original published paper (version of record):

Aspeteg, J., Bergek, A. (2020). The value creation of diffusion intermediaries: Brokering mechanisms and trade-offs in solar and wind power in Sweden. Journal of Cleaner Production, 251. http://dx.doi.org/10.1016/j.jclepro.2019.119640

N.B. When citing this work, cite the original published paper. 


\title{
The value creation of diffusion intermediaries: brokering mechanisms and trade-offs in solar and wind power in Sweden
}

\author{
Joakim Aspeteg and Anna Bergek* \\ Department of Technology Management and Economics, Chalmers University of Technology, \\ SE-41296 Gothenburg, Sweden.Email: anna.bergek@,chalmers.se \\ * Corresponding author. Telephone: +46-31-772 6962.
}

Declarations of interest: none.

\begin{abstract}
This paper focuses on diffusion-oriented innovation intermediaries ("diffusion intermediaries"), i.e. actors that function as brokers between technology adopters and the providers of resources needed to implement a new technology that is available more or less "off-the-shelf". It investigates how such actors create value for adopters of new technologies as well as the trade-offs they face. An interview-based, qualitative survey of 14 Swedish consultants and project developers involved in solar PV and wind power reveals that diffusion intermediaries create value mainly through technology transfer and coordination of various actors throughout the planning and implementation of turnkey projects. There is evidence of trade-offs related to value capture as well as between different value dimensions (e.g. between quality control and legitimacy). These findings have important implications for the design of strategies and policies to leverage value creation and handle trade-offs to avoid negative effects on projects, companies, and the overall diffusion of cleaner technologies.
\end{abstract}

Keywords: innovation intermediary; broker; intermediation; business model; value capture

\section{Introduction}

Several of the key frameworks in the field of sustainability transitions emphasize the crucial role different types of actors play in niche formation, the development and diffusion of new technologies, and various forms of institutional entrepreneurship (cf. e.g. Bergek et al., 2008; Geels, 2011; Smith, 2003). Actors can, for instance, contribute to sustainability transitions by furthering new environmental technologies and solutions (Bergek et al., 2008), disrupting unsustainable sociotechnical regimes (Kivimaa, 2014), opening up emerging niches to a wider set of users (Gibbs and O'Neill, 2014), lobbying for wider system change (Smith, 2003), and engaging in system-building activities (Hellsmark and Jacobsson, 2009). 
In this paper, we focus on one particular type of actor: the innovation intermediary, that is "an organization or body that acts as an agent or broker in any aspect of the innovation process between two or more parties" (Howells, 2006, p. 720). More specifically, we focus on diffusion-oriented innovation intermediaries ("diffusion intermediaries" for short), that is middle actors (Parag and Janda, 2014) such as project developers or consultants that act as brokers between, on the one hand, technology adopters (i.e. those who invest in, implement and operate/use a new technology) and, on the other hand, the providers of inputs needed to adopt and implement a new technology that is available more or less "off-the-shelf" (e.g., technology, funding, and environmental permits) (Bergek, 2019a).

These actors can potentially improve the rate and quality of implementation of sustainable innovations. Previous research show that adopters of, for example, renewable energy technologies face a diverse set of actor- and system-level challenges (Mignon and Bergek, 2016), and that intermediaries can help them handle some of these (Mignon, 2016). For instance, adopters often lack knowledge about the technology, and diffusion intermediaries can help them evaluate and select technologies and suppliers. Adopters also face considerable institutional challenges, for example related to support systems and permit applications, which diffusion intermediaries can guide them through. In addition, it has been argued that diffusion intermediaries can create sustainable value at the societal level (Muñoz and Cohen, 2018), by promoting the diffusion of new technologies (Dicecca et al., 2016). This relates to the argument that an "ecology" of intermediaries is needed to advance sustainability transitions (Kivimaa et al., 2019b). Some have also suggested that intermediaries could be used as a policy instrument to accelerate innovation and sustainability transitions (Klerkx and Leeuwis, 2008b).

However, most previous studies on intermediaries focus either on innovation intermediaries that are focused on technology and product development rather than adoption and diffusion, or on so-called "transition intermediaries" that contribute to sustainability transitions by linking actors and activities or connecting transition visions and demands with existing regimes (Kivimaa et al., 2019a). These differ from diffusion intermediaries in several ways. Most notably, both development-oriented innovation intermediaries (Katzy et al., 2013) and transition intermediaries (Kivimaa et al., 2019b) primarily act in early phases of development. Many transition intermediaries also act at the system level rather than in relation to specific adoption processes (Gliedt et al., 2018). For example, they aggregate learning outcomes between local projects and global niches (Matschoss and Heiskanen, 2017). Since the role of 
intermediaries differs between different phases (Katzy et al., 2013; Kivimaa et al., 2019b) and levels (Mignon and Kanda, 2018), this implies that the results from these studies do not necessarily apply to diffusion intermediaries. From a theoretical perspective, there is therefore a lack of knowledge about the mechanisms through which diffusion intermediaries create value for their clients and for society as a whole.

Moreover, many sustainability-oriented intermediaries are created or funded by government organizations to further innovation and sustainability transitions (Gliedt et al., 2018). In contrast, diffusion intermediaries are for the most part private companies that have different priorities than, for example, local authorities (cf. Bush et al., 2017), business development agencies (Kanda et al., 2018) or government-affiliated organizations (cf. Kivimaa, 2014). In particular, they can be expected to work in their own self-interest rather than towards some larger societal goal (Klerkx et al., 2015). This implies that conflicts of interest are likely to occur regarding value capture, i.e. how the created value should be distributed between the intermediary and other parties (Zott et al., 2011). For example, there is a potential trade-off between a high degree of customization, which provides value for the client, and the cost associated with this for the intermediary (cf. Mizik and Jacobson, 2003). There can also be trade-offs between achieving business goals and contributing to technology diffusion and sustainability transitions (Gibbs and O'Neill, 2014). What value capture trade-offs diffusion intermediaries face, how they handle them and what impact this might have on the implementation of sustainable innovations is, however, not known. From a practice perspective, more knowledge on potential trade-offs is therefore needed to be able to design strategies and policies to counteract any negative effects these might have on adoption and diffusion processes.

Against this background, the purpose of this paper is to investigate through which mechanisms diffusion intermediaries, as brokers, create value for adopters of sustainable innovations and what conflicts of interests and trade-offs they face in relation to value capture. Our empirical focus is intermediaries working with solar PV and wind power technologies in Sweden, for example specialized consultants, project developers and retailers. These are located between the households, housing associations, companies, or financial investors that want to invest in and implement a solar PV or wind power plant and providers of the various inputs that are needed to make this happen, for example equipment suppliers, banks, installers, construction companies, and government agencies. 
By fulfilling this purpose, the paper makes two main contributions. The main theoretical contribution is to identify the mechanisms through which intermediaries enable the adoption and larger-scale diffusion of innovations, highlighting the main similarities and differences between diffusion intermediaries and development-oriented innovation intermediaries and transition intermediaries. In brief, the study shows that diffusion intermediaries create value mainly through transfer and coordination rather than through match-making, and that they focus on providing traditional economic values rather than meeting sustainability goals. This contributes to the discussion about the roles different actors play in the "dynamic ecology of differently positioned intermediaries, with differing competences, remits and operational modes", which exists around emerging sustainable innovations (Kivimaa et al., 2019a, p. 1063). Second, the paper contributes to practice by identifying potential trade-offs that diffusion intermediaries face in relation to value creation and capture. These include clientand supplier- related value capture trade-offs (e.g. between the intermediaries' profit margins and customer values such as quality and legitimacy) as well as trade-offs between different value dimensions (e.g. compromises between quality and legitimacy). From the point of view of company strategy, these trade-offs need to be handled for the intermediary to achieve longterm economic sustainability and gain trust and legitimacy in the eyes of other stakeholders. From the point of view of policy, such trade-offs are relevant because they can reduce the intermediaries' willingness and ability to contribute to an effective implementation of sustainable innovations and limit their usefulness as a policy instrument to promote sustainable transitions in important societal systems of production and consumption, such as energy supply.

The following section defines and describes diffusion intermediaries in relation to previous literature and discusses value creation and value capture trade-offs. In Section 3, the methodology of the empirical study is described. The empirical findings are described and analysed in Section 4. Section 5 summarizes the main conclusions and discusses their implications for theory and practice.

\section{Theoretical background and analytical framework}

This section first introduces and defines the concept of diffusion intermediaries (Section 2.1) and then moves on to describe how the value creation of such intermediaries can be conceptualized in terms of three brokering mechanisms (Section 2.2) and discuss potential 
conflicts of interest and trade-offs related to value capture (Section 2.3). The section ends with a brief summary of the analytical framework (Section 2.4).

\subsection{Diffusion-oriented innovation intermediaries}

Innovation intermediaries have been a topic of interest for innovation scholars for quite some time. The first decades of research were reviewed in the seminal paper by Howells (2006), who also put forward a tentative definition of an innovation intermediary:

"An organization or body that acts as an agent or broker in any aspect of the innovation process between two or more parties. Such intermediary activities include: helping to provide information about potential collaborators; brokering a transaction between two or more parties; acting as a mediator, or go-between, bodies or organizations that are already collaborating; and helping find advice, funding and support for the innovation outcomes of such collaborations." (Howells, 2006, p. 720)

From this definition follows that a main feature of intermediaries is that they act in-between two or more other parties. At the level of an innovation project or a company, which is the focus of this paper, ${ }^{1}$ this implies that they act between on the one hand a client, who has a specific problem that needs to be solved, and on the other hand some kind of (dispersed) "sources of knowledge" that can be used to solve that problem (Colombo et al., 2015; Katzy et al., 2013).

Which actors take on a role as innovation intermediaries differ between different phases of the innovation process (cf. Janssen et al., 2014; Katzy et al., 2013). So far, most of the literature has been focused on "development-oriented" innovation intermediaries, such as consultant or knowledge intensive business service (KIBS) companies (cf., e.g., Bessant and Rush, 1995; Klerkx and Leeuwis, 2008a). They are involved in the development and transfer of new technologies and are located between on the one hand technology/innovation seekers and on the other hand technology/innovation providers (Holzmann et al., 2014), holders (Von Nell and Lichtenthaler, 2011), or solvers (Abbate et al., 2013). Similarly, so-called "transition intermediaries" (Kivimaa et al., 2019a) are primarily active in early transition phases and become less visible as a technology matures (Kivimaa et al., 2019b).

In contrast, the focus of this paper is innovation intermediaries involved in the acceleration and large-scale diffusion of new technologies that have already been developed enough to be

\footnotetext{
${ }^{1}$ More 'systemic' intermediaries, which function at the level of an innovation network or innovation system (c.f. e.g. Küçüksayraç et al., 2015) and are concerned with network orchestration (Katzy et al., 2013) are not included in the following discussion.
} 
available more or less off-the-shelf. In this paper, these are referred to as "diffusion-oriented" innovation intermediaries or "diffusion intermediaries" for short.

Early literature on innovation diffusion highlights the importance of change agents and specialized third-party actors that influence adoption decisions (cf. Rogers, 2003) and help adopters adapt and implement the technologies they have decided to adopt (cf. Stankiewicz, 1995). More recent studies of intermediary organizations such as industry associations (Winch and Courtney, 2007), knowledge transfer organisations (Dicecca et al., 2016), advice centres (Theodorakopoulos et al., 2014) and installers (Benouniche et al., 2016) show that they are engaged in transferring new technologies and practices from innovating organizations to households or small companies. One way of thinking of diffusion intermediaries is, thus, as actors located somewhere downstream in the supply chain that act as brokers between technology suppliers and adopters (cf. Stewart and Hyysalo, 2008).

However, technology suppliers are not the only actors that provide important inputs to the adoption process. For example, in the context of renewable energy, which is the empirical focus of this paper, land owners and grid operators provide necessary infrastructure, government agencies provide, for example, building and environmental permits and economic subsidies, and financial actors provide investment capital (Bergek, 2019a). Diffusion intermediaries involved in this field are, thus, involved in a many-to-one-to-one relationship (cf. Howells, 2006) with a diverse set of stakeholders (see Figure 1).

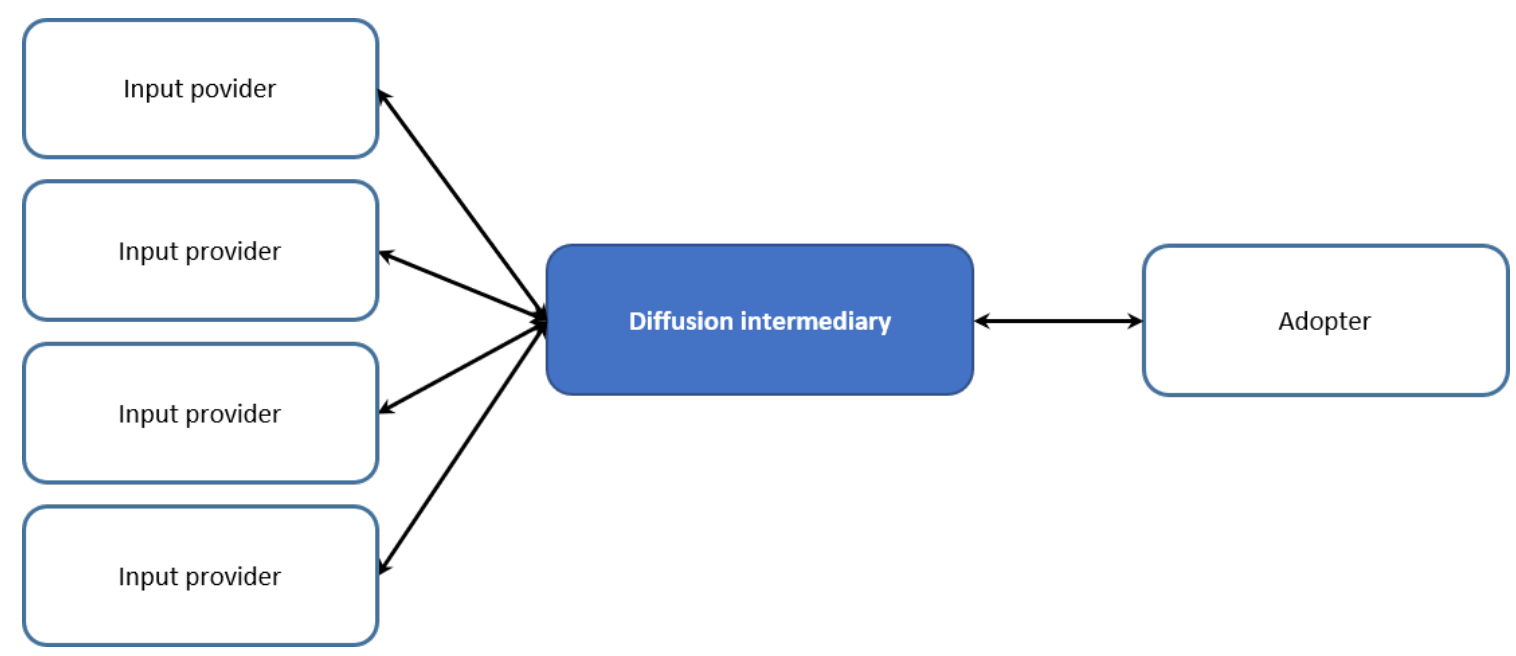

Figure 1: Diffusion intermediaries as brokers between adopters and various input providers 


\subsection{Value creation through brokering}

From the point of view of a company, value is most often described in terms of economic value (profit), although some companies - as shown in the literature on sustainable entrepreneurship and sustainable business models - also associate value with social and environmental benefits (Bocken et al., 2014; Boons and Lüdeke-Freund, 2013). From the point of view of a client, value refers to all types of benefits or utilities the company's product-service bundle brings (Osterwalder and Pigneur, 2010). In the context of innovation diffusion, some of these values are related to the client's overall motives to adopt a new technology. In relation to renewable energy technology, such motives can, for example, be to get access to environmentally friendly electricity (environmental value), become independent from utilities (social value) and save money (economic value) (Bergek and Mignon, 2017). However, since diffusion intermediaries act in between technology suppliers and technology adopters, the values we are primarily interested in here are those they add "on top of" the benefits derived from the technology as such, which constitute their unique value proposition as intermediaries.

As mentioned in the introduction, there are good reasons to believe that diffusion intermediaries can make important contributions to their clients' adoption processes. For example, empirical studies have shown that they demonstrate the benefits of new technologies to potential end users (Stewart and Hyysalo, 2008), recommend or validate specific solutions (Owen et al., 2014; Theodorakopoulos et al., 2014), facilitate the supply of inputs (e.g., knowledge technology or funding) (Dicecca et al., 2016; Poncet et al., 2010), specify and adapt technologies to local contexts (Benouniche et al., 2016), and bridge gaps in culture, motivation, knowledge and skills between innovators and end users (Edler and Yeow, 2016).

However, although these and other studies have identified a large and varying number of activities that actors described as intermediaries can perform in relation to innovation diffusion and sustainability transitions (for a recent overview, see Gliedt et al., 2018), it is far from clear which of these activities actually constitute intermediation. Indeed, most innovation intermediaries are not specialized on intermediation but also do other things, for example provide services (Nilsson and Sia-Ljungström, 2013). In the case of renewable energy technology, some intermediaries even produce electricity (Bergek, 2019a). This implies that it is unclear to what extent and how diffusion intermediaries actually create 
"otherwise unobtainable value" (Håkanson et al., 2011) through intermediation versus other types of activities.

How companies create value is in focus in the business model literature. A business model describes the "business logic" of a specific company (Zott et al., 2011), i.e. "the rationale of how an organization creates, delivers and captures value" (Osterwalder and Pigneur, 2010, p. 14). ${ }^{2}$ It specifies the company's value proposition, its customers, and the boundary-spanning activity network or value chain it exploits to create and deliver value (Bocken et al., 2014). This involves choices with regard to, for example which bundle of products to offer, what customer segments to target, what activities to perform in-house, whom to collaborate with and what revenue streams to exploit (Osterwalder et al., 2005).

Although intermediaries play an important role in some of the business models described in previous literature, for example “open” business models (Osterwalder and Pigneur, 2010), we have not found any descriptions of an archetypical business model for intermediaries as such. However, as defined in Section 2.1 innovation intermediaries are brokers. ${ }^{3}$ This implies that different types of brokering should be at the heart of their value proposition and the activities and partnerships they engage in. We conceptualize brokering in terms of three broadly defined mechanisms (cf. Spiro et al., 2013):

- Transfer implies that the broker conveys resources, typically knowledge or technology, from one party to another. Some innovation intermediaries initiate the transaction but do not take ownership of the technology (Håkanson et al., 2011), whereas others take a more active part in the transfer process by combining the knowledge that is being transferred with complementary pieces of knowledge gained in previous projects (cf. Abbate et al., 2013; Hargadon and Sutton, 1997) or even providing turnkey solutions to their clients (Colombo et al., 2015).

\footnotetext{
2 The business model, thus, enables an organization to create value and appropriate part of that value (Zott and Amit, 2010). This implies that value creation and capture are seen as the outcome of a business model rather than as components of the business model itself (for a contrasting perspective, see: Baden-Fuller and Mangematin, 2013; Clauss, 2017).

${ }^{3}$ Howells (2006) does not explicitly explain his distinction between agents and brokers. Chesbrough (2006, p. 140) define agents as actors that "represent one side of a transaction" and "owe their allegiance to their clients". Similarly, Rogers (2003) describes a change agent as someone who is responsible to a bureaucracy (the change agency). Since agents, thus, represent one of the involved parties, it can be questioned whether they are a third party. We have therefore chosen not to include agents in our definition of intermediaries.
} 
- In matchmaking, the broker facilitates the formation of a direct relationship between the parties. The contribution of an innovation intermediary can for example include identifying and selecting partners (Bessant and Rush, 1995) and/or shaping the terms of the transaction (Chesbrough, 2006).

- Coordination implies that the broker allows the two parties to interact without creating a direct relationship between them, for example by aligning contributions from different parties involved in a project (Klerkx and Leeuwis, 2009).

The brokering mechanisms of development-oriented intermediaries are quite well understood. Indeed, the literature on open innovation has described in some detail how developmentoriented intermediaries engage in 'inbound' and 'outbound' technology transfer processes, aimed at sourcing technology from external partners or selling technology to other supplyside companies (e.g. through patenting or licensing) (cf. Dahlander and Gann, 2010). It has also shown how they act as match-makers, helping companies find collaboration partners for new product development projects (Cantner et al., 2011). Coordination, in contrast, does not seem to be an important part of their value creation repertoire.

The literature on diffusion intermediaries is more tentative. There is some evidence that diffusion intermediaries engage in transfer of, for example, best practices (Dicecca et al., 2016), information (Caiazza and Volpe, 2017), and technical equipment (Benouniche et al., 2016; Karakaya et al., 2016). There are also examples of match-making, such as when diffusion intermediaries help customers get in direct contact with technology suppliers or sources of finance (Dicecca et al. 2016, Poncet et al. 2010). Some studies also mention that diffusion intermediaries help adopters deal with a wide range of challenges that originate from different technical, administrative, commercial, and financial spheres (Benouniche et al., 2016; Mignon and Bergek, 2016), which could be interpreted as coordination. However, these indications of brokering do not provide enough knowledge to understand how prevalent different brokering mechanisms are and to what extent they create value. Moreover, since few of these studies relate the identified activities explicitly to brokering, there is no clear understanding of how transfer, match-making and coordination are manifested in more concrete intermediation activities (cf. Martiskainen and Kivimaa, 2018).

Against this background, our first research question, which aims at shedding light on how value is created through brokering in a diffusion context, is: 


\section{$R Q$ 1: On what types of brokering mechanisms is value creation by diffusion intermediaries based and what intermediation activities are carried out as part of those mechanisms?}

\subsection{Value capture, conflicts of interests and trade-offs}

From a stakeholder perspective, one of the key tasks of an intermediary is to balance different stakeholder interests (Agogué et al., 2017) and, ideally, reach a so-called "win-win" situation (Hahn et al., 2010). In fact, it has even been suggested that the role of any company is "to meet the demands of customers, suppliers, employees, communities, and financiers, so that all win" (Freeman, 2010, p. 8). This is also emphasized in the business model literature, which describes business models as "geared toward total value creation for all parties involved" (Zott and Amit, 2010, p. 218) and in the literature on sustainable entrepreneurship, which emphasizes the company's responsibility to consider a wide variety of stakeholders, including the society at large (Brennan and Tennant, 2018).

Nevertheless, the definition of a business model cited above also emphasizes value capture. Even if the overall goal is to create value for all stakeholders, the exact distribution of this value - i.e. how much value a focal company will be able to capture and how much its clients and partners will appropriate - depends on the business model choices it makes (Mizik and Jacobson, 2003; Zott et al., 2011). For example, differentiation and customization create value for clients, but can be very costly for the intermediary, and unless clients are willing to pay for customization, they will capture more value than the intermediary. This implies that conflicts of interest can occur between the company and its clients or suppliers depending on each party's bargaining power (Porter, 1980), and that the company might have to make trade-offs between different stakeholder interests (Freeman, 2010). This applies even more to diffusion intermediaries than to the average company, since they are involved in many-to-one-to-one relationships and therefore have to handle many different stakeholders at the same time.

A number of problems are associated with this for intermediaries, individual adoption projects and the overall diffusion process. From the point of view of the diffusion intermediary, the business model has to be designed in such a way that clients and suppliers get enough value to be satisfied, while the intermediary still makes enough profit. This involves difficult choices related to, for example, which services to offer as part of the value proposition, whether to outsource key activities or keep them inhouse, and how close client and supplier relationships to build (Osterwalder and Pigneur, 2010). It can also require the intermediary to compromise 
its own internal values, for example if a 'green' image does not appeal to prospective clients (Gibbs and O'Neill, 2014).

From the point of view of individual adoption projects, trade-offs between different interests can have a direct impact on implementation quality, depending on which interests are prioritized. Intermediaries sometimes act in their own self-interest rather than in the interest of the projects (Klerkx et al., 2015) or prioritize customer preferences that lead to less efficient projects (cf. Mignon and Bergek, 2016). In other cases, they prioritize the interests of other stakeholders, such as financial and insurance partners, over their clients, which could result in more productive and robust projects (Överholm, 2017). They could also find it difficult to balance policy goals with the interests of their clients (Klerkx and Leeuwis, 2008a) or their own goals and interests (Gibbs and O'Neill, 2014). Such trade-offs tend to spill over to system-level effectiveness and, thus, influence the overall diffusion process.

This discussion raises questions about how value is distributed between diffusion intermediaries and their primary stakeholders and which trade-offs diffusion intermediations make with regard to this. Against this background our second research question, which aims at furthering our understanding of trade-offs associated with value capture, is:

\section{$R Q$ 2: What types of value capture trade-offs do diffusion intermediaries make in relation to adopters and input providers?}

\subsection{Summary and analytical framework}

To summarize the discussion above, we propose a framework (see Figure 2) in which diffusion intermediaries are located downstream in the supply chain, between adopters and various input providers and in which Spiro et al.'s (2013) three brokering mechanisms are explicitly considered as the core of the diffusion intermediaries' value creation. The framework also highlights value creation and value capture as two related aspects of a business model and indicates that intermediaries' value capture ambitions can result in tradeoffs in relation to adopters and input providers. 


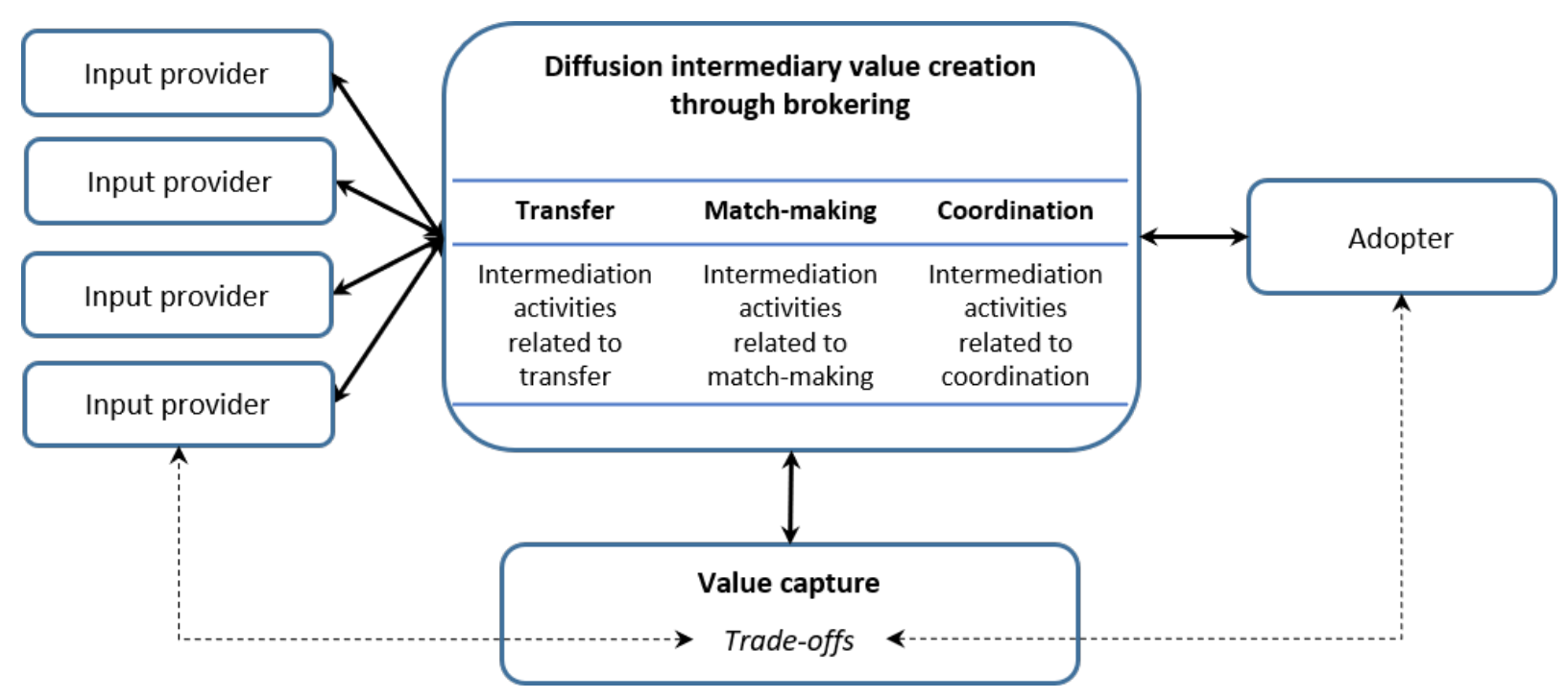

Figure 2: Analytical framework

\section{Methodology}

\subsection{Study design and operationalization of key constructs}

Studies of the value creation of intermediaries are rare. The present study is, thus, of an explorative character and we, therefore, chose a qualitative research approach. Since we, based on our research questions, were interested in comparing the value creation and value capture of a variety of diffusion intermediaries, we chose an interview-based "qualitative survey" approach (cf. Jansen, 2010). This is somewhat similar to a multiple case study approach, with the main difference that the qualitative survey covers a larger set of companies about which a more limited amount of qualitative data is collected based on one or a few interviews per company. Another difference is that multiple case studies tend to be based on a predefined understanding or expectation of similarities and differences between the cases (Yin, 1984), which is not the case in an exploratory study.

The study covers intermediaries working within two renewable energy technologies (RETs) wind power and solar PV - in Sweden. What made the Swedish case interesting was the fact that while Sweden does not have any wind turbine or solar PV system supply industries to speak of (and therefore sources technology from global value chains), there is a rather welldeveloped ecology of diffusion intermediaries in several technology fields. Previous studies had also shown that diffusion intermediaries play an important role in technology adoption in both wind power and solar PV (Mignon, 2016; Mignon and Bergek, 2016; Palm, 2015). These cases could therefore provide unique insights of the values diffusion intermediaries create and, especially, what trade-offs they have to handle - if actors in a relatively well-developed 
industry struggle with trade-offs, then actors in less developed industries most likely face even larger challenges. We included both wind power and solar PV in order to see if value creation, value capture, and trade-offs associated with these depend on the complexity and scale of the projects being implemented. Wind power project development involves a wider variety of stakeholders and is also more complicated from a regulatory perspective than solar PV.

As defined in Section 2, diffusion intermediaries are actors located somewhere downstream in the supply chain and acting as brokers between suppliers of input to the adoption process and the technology adopters. In this context, the adopter is the individual or organization that decides to invest in and implement a technology. Adopters can, for example be people who invest in solar modules to put on the roof to their own houses, housing associations investing in a solar plant to supply their tenants with renewable electricity or financial investors investing in large-scale solar or wind power plants. Since it was difficult to know which actors acted as brokers before studying them, we consulted previous literature on downstream actors in wind power and solar PV (e.g., Mignon, 2016; Palm, 2015; Strupeit and Palm, 2016). These studies indicated that in the chosen technology fields, consultants and project developers correspond well to the theoretical definition of diffusion intermediaries and we therefore focused our study on such actors. In the case of solar PV, however, the value chain sometimes includes other intermediaries than consultants/project developers, such as wholesalers and retailers (Palm, 2015). We therefore decided to also include such actors, which then are located between the technology supplier and the consultant/project developer rather than the final adopter.

Our study covers 14 private diffusion intermediaries working with wind power or solar PV (see Table 1). The selection was made in several steps. We first used secondary data, such as industry overviews, to identify intermediaries that matched the criteria mentioned in the previous paragraph. It should be noted that there are much fewer wind power intermediaries than solar PV intermediaries in Sweden, which limited the total number of companies since we wanted a balanced sample. The final selection was based on a combination of relevance and convenience. With regard to relevance, we focused on variety/diversity as a selection criterion to get a broad understanding of diffusion intermediaries, considering the exploratory nature of the study (cf. Flyvbjerg, 2006; Seawright and Gerring, 2008). We therefore aimed at including different types of intermediaries, for instance consultants, installers, wholesalers and project developers, as well as older and younger companies. Based on a common 
distinction in previous literature, we also aimed at including both specialized intermediaries (i.e. intermediaries that only provide intermediation services) and unspecialized intermediaries (i.e. intermediaries that are also involved in other types of business activities) (cf. Bergek, 2019a). However, since it was somewhat difficult to find unspecialized solar PV intermediaries, we did not achieve a perfect balance between these categories in the end. With regard to convenience, some of the solar PV intermediaries we approached initially did not have time to participate in the study. Later follow-up interviews have, however, confirmed that the findings of this study is relevant also for these.

Table 1. Companies included in the qualitative survey.

\begin{tabular}{|c|c|c|c|c|c|c|}
\hline & $\begin{array}{l}\text { Start } \\
\text { year }\end{array}$ & Type & Main business & $\begin{array}{l}\text { Type of } \\
\text { intermediary }\end{array}$ & $\begin{array}{l}\text { Year of } \\
\text { interview }\end{array}$ & $\begin{array}{l}\text { Interviewee } \\
\text { position }\end{array}$ \\
\hline Wind A & 1990 & $\begin{array}{l}\text { Private } \\
\text { company }\end{array}$ & $\begin{array}{l}\text { Wind power } \\
\text { development }\end{array}$ & Specialized & 2017 & Sales manager \\
\hline Wind B & 2005 & $\begin{array}{l}\text { Private } \\
\text { company }\end{array}$ & $\begin{array}{l}\text { Wind power } \\
\text { development }\end{array}$ & Specialized & 2013 & $\begin{array}{l}\text { Group } \\
\text { managers }\end{array}$ \\
\hline Wind $\mathrm{C}$ & 2009 & $\begin{array}{l}\text { Private } \\
\text { company }\end{array}$ & $\begin{array}{l}\text { Wind power } \\
\text { development }\end{array}$ & Specialized & 2017 & $\begin{array}{l}\text { Managing } \\
\text { director }\end{array}$ \\
\hline Wind D & 2010 & $\begin{array}{l}\text { Private } \\
\text { company }\end{array}$ & $\begin{array}{l}\text { Wind power } \\
\text { development }\end{array}$ & Specialized & 2017 & $\begin{array}{l}\text { Project } \\
\text { manager }\end{array}$ \\
\hline Wind $\mathrm{E}$ & 1992 & $\begin{array}{l}\text { Private } \\
\text { company }\end{array}$ & $\begin{array}{l}\text { Electricity } \\
\text { production }\end{array}$ & Unspecialized & 2011 & $\begin{array}{l}\text { Managing } \\
\text { director }\end{array}$ \\
\hline Wind $F$ & 2006 & $\begin{array}{l}\text { Private } \\
\text { company }\end{array}$ & $\begin{array}{l}\text { Electricity } \\
\text { production }\end{array}$ & Unspecialized & 2012 & $\begin{array}{l}\text { Business } \\
\text { manager }\end{array}$ \\
\hline Wind $\mathrm{G}$ & 2012 & $\begin{array}{l}\text { Public } \\
\text { company }\end{array}$ & $\begin{array}{l}\text { Electricity } \\
\text { production }\end{array}$ & Unspecialized & 2017 & $\begin{array}{l}\text { Business } \\
\text { manager }\end{array}$ \\
\hline Solar A & 2012 & $\begin{array}{l}\text { Private } \\
\text { company }\end{array}$ & $\begin{array}{l}\text { Solar PV } \\
\text { consulting }\end{array}$ & Specialized & 2017 & $\begin{array}{l}\text { Managing } \\
\text { director }\end{array}$ \\
\hline Solar B & 2011 & Cooperative & $\begin{array}{l}\text { Energy \& } \\
\text { environmental } \\
\text { consulting }\end{array}$ & Unspecialized & 2017 & $\begin{array}{l}\text { Chairman of } \\
\text { the board }\end{array}$ \\
\hline Solar C & 2010 & $\begin{array}{l}\text { Private } \\
\text { company }\end{array}$ & $\begin{array}{l}\text { Solar PV } \\
\text { development }\end{array}$ & Specialized & 2017 & $\begin{array}{l}\text { Managing } \\
\text { director }\end{array}$ \\
\hline Solar D & 2012 & $\begin{array}{l}\text { Private } \\
\text { company }\end{array}$ & $\begin{array}{l}\text { Solar PV } \\
\text { development }\end{array}$ & Specialized & 2017 & $\begin{array}{l}\text { Chairman of } \\
\text { the board }\end{array}$ \\
\hline Solar E & 2014 & $\begin{array}{l}\text { Private } \\
\text { company }\end{array}$ & $\begin{array}{l}\text { Solar PV } \\
\text { development }\end{array}$ & Specialized & 2017 & $\begin{array}{l}\text { Chairman of } \\
\text { the board }\end{array}$ \\
\hline Solar F & 2013 & $\begin{array}{l}\text { Private } \\
\text { company }\end{array}$ & $\begin{array}{l}\text { Solar PV } \\
\text { wholesale }\end{array}$ & Specialized & 2017 & $\begin{array}{l}\text { Managing } \\
\text { director }\end{array}$ \\
\hline Solar G & 2008 & $\begin{array}{l}\text { Private } \\
\text { company }\end{array}$ & $\begin{array}{l}\text { Electric } \\
\text { installations }\end{array}$ & Unspecialized & 2017 & $\begin{array}{l}\text { Business } \\
\text { manager }\end{array}$ \\
\hline
\end{tabular}


A limitation of the study is that it is restricted to the Swedish national context. Sweden is located in Northern Europe and is a capitalist economy. A liberalization of the electricity market was completed about 20 years ago, which implies that grid operations are organizationally separated from production and retail. There is no central planning of investments in new production capacity. New electricity producers can enter the market freely and there is a large number of different types of actors involved in renewable electricity production, including big utilities and municipal energy companies, municipalities, diversified companies, churches, farmers, economic associations and households (Bergek et al., 2013). While these characteristics are similar to other Western European countries, particularly within the EU, they most likely differ substantially from many other countries. This implies that the findings of this study cannot necessarily be generalized to all other national contexts.

\subsection{Data collection and analysis}

The data were mainly collected through interviews, in two different time periods. Most of the interviews were done in 2017, specifically for this study, but we also re-used three interviews from a previous study, conducted in $2011-2013 .{ }^{4}$ We mainly interviewed the managing director or chairman of the board. In some cases, however, the interviewee was a sales person or sales/business manager (see Table 1). We explained the purpose of the study and let the contact person decide who in the company was best suited to answer our questions.

All the interviews from 2017 were conducted face-to-face. The interviews were conducted in a semi-structured way, following an interview guideline covering four main areas: (1) general information about the company, (2) information about the industry as a whole, (3) the company's business model with regard to renewable energy technology, and (4) challenges and risks. The last two areas were the ones used to answer the research questions of this paper and more detailed information about the topics covered within each of these are provided in Appendix A. With regard to the business model, we first asked general questions about each company's business and then more detailed questions about its business model. The latter questions were based on the Osterwalder and Pigneur (2010) framework, which defines the main components of a business model as value proposition, customer segments, customer relationships, channels, key activities, key partners, key resources, revenue streams, and cost structure. We also asked the interviewee to describe a typical project from start to finish to get

\footnotetext{
${ }^{4}$ This was done with the consent from the original investigator and the interviewees had also consented to the interviews being used as a basis for multiple articles.
} 
a more detailed and concrete picture of the activities involved. With regard to challenges and risks, we asked questions to explore the companies' perceptions of success criteria, trade-offs, conflicts of interest, and challenges. The length of the interviews varied between approximately 40 minutes and 1 hour and 40 minutes, depending on, for example the technology and the complexity of the company's business model. The interviews were audiotaped and transcribed word-by-word.

The earlier interviews were conducted as part of a study of the collaboration between wind power diffusion intermediaries and their clients (Mignon, 2016). They were conducted face to face in a semi-structured way, covering the entire implementation process. The interviews included much useful information about the intermediaries' business models but were not specifically focused on those. The interview transcripts were made available to us by the researcher conducting the interviews. In two of the cases, we also contacted the companies to ask for complementary information regarding their business models. Since conditions for wind power projects in Sweden have changed somewhat since 2013, with larger projects being built and new types of adopters coming in, the relevance of including older interviews could perhaps be questioned. However, there was more agreement than disagreement between the two sets of interviews with regard to the brokering mechanisms and trade-offs. The main difference is that more recent wind power projects involve less of technology transfer from equipment suppliers to the adopters and that intermediaries to a larger extent co-own the plants than before. Moreover, two of the new interviews were conducted with companies that have been in the wind power development business for some time, and these interviews both helped us understand these differences better and showed that the main mechanisms had not changed much since the older interviews were made.

The transcripts from the two sets of interviews were analyzed using the analytical framework as a guide. In short, we first identified the central business model components for each intermediary (see Appendix B). In some cases, complementary information about some components was collected from the companies' web sites or through follow-up contacts with the interviewees via telephone or email. Based on this, we identified the main value-creating activities and categorized these in terms of the three brokering functions following the definitions of Spiro et al. (2013) (as described in Section 2). We then analyzed each model to identify the main trade-offs, both between the intermediary and its stakeholders (especially the client) and between different stakeholders. This analysis was based both on the questions related to challenges and risks and our own conclusions from the business model analysis. We 
then compared the intermediaries to identify common patterns. Because of the differences between wind power and solar PV intermediaries, we first compared companies within each technology before analyzing similarities and differences between the two technologies.

\section{Brokering mechanisms and trade-offs: empirical findings}

This section summarizes the main empirical findings in terms of the value creation and tradeoffs of the wind power and solar PV intermediaries included in our study. First, we analyse each technology separately, starting with a brief description of the intermediaries' main business focus and the actors involved in the value proposition in focus here (for a complete overview of the intermediaries' business models, see Appendix B) and continuing with an analysis of the brokering mechanisms and trade-offs associated with value creation and capture. Second, we compare the findings from the two technologies and discuss the findings in relation to previous literature.

\subsection{Wind power intermediaries}

The seven wind power intermediaries included in this study differ somewhat in terms of how they define their main business. Whereas Wind A-D are specialized wind power project developers, Wind E-G are vertically integrated and focused on electricity production and therefore have a broader value proposition and set of activities. ${ }^{5}$ The focus here is on the wind power development business, which all of them have in common. This involves a project developer positioned between on the one hand one or more clients (often utilities, diversifying companies or financial investors such as pension funds) and on the other hand various input providers, such as turbine suppliers, environmental permit providers, land owners, and subcontractors.

\subsubsection{Value creation through brokering}

The main value proposition of the wind intermediaries is the development of turnkey projects. They take care of the entire process from site inspection to an operational wind power plant and, thus, create value for their clients by offering total solutions. However, their economic model implies that they sell shares in plants rather than the plants as such (with the exception of Wind D); after a permit has been secured, each plant is divided into shares, which are

\footnotetext{
${ }^{5}$ In addition to developing and building wind power plants, they retain some ownership of the plants, operate them and sell the generated electricity. One of them, Wind F, also operates wind power plants on behalf of other companies.
} 
offered to potential investors. This implies that customers do not adopt the technology per se, but rather make a financial investment. Therefore, customer value could also be described in terms of return on investment (ROI).

The wind intermediaries create these values mainly through two of the brokering mechanisms and the activities associated with these: transfer and coordination. In this context, transfer consists mainly of technology procurement and includes technology and supplier assessment and selection. For the most part this is done through an open tender, where different turbine suppliers compete for the contract by specifying the turbine model they suggest and making a budget and implementation plan for the project. ${ }^{6}$ The intermediary assesses their offers, selects a supplier and turbine model on behalf of the adopter and places the order. In contrast, Wind D negotiates directly with a few selected suppliers in order to make sure the turbine is appropriate for the site: “... above all, the turbine must fit the site, that's the most important thing" (Wind D).

Coordination includes two main types of intermediation activities: assemblage of different types of inputs and management of input providers. In order to secure inputs, the intermediary has to handle a number of different input providers throughout the implementation process. This takes place at two different levels. First, the wind power project development process is complex and requires a number of different sub-processes, for example (a) site exploration, (b) contract negotiations with landowners, (c) environmental permit/concession application, (e) turbine procurement (as described in the previous paragraph); and (f) construction management. In order to deliver a turnkey project, the wind intermediary has to coordinate all these processes as well as the actors involved in them. For example, site exploration includes wind measurements, which are either done by an external consultant or have to be validated by a third party, and, as mentioned above, turbine procurement involves communicating with several turbine suppliers.

Second, some of these sub-processes are complex in themselves and involve several different input providers. Most notably, securing an environmental permit involves, among other things, performing or commissioning environmental impact assessments (EIA) and managing consultation processes with authorities, agencies and the general public. EIAs include impact

\footnotetext{
${ }^{6}$ Each supplier hands in an offer, specifying the turbine model they suggest; the projected production of the plant; the price and other parts of the deal (e.g., warranties and service agreements); requirements with regard to foundation, roads and crane areas; and other conditions related to delivery and construction.
} 
studies relating to sound, visual effects, wildlife, and endangered species (e.g. bats and eagles), as well as geotechnical and cultural heritage investigations and studies of the effects of the project on competing interests (e.g. aviation). Although most of the companies coordinate this process internally (except Wind D, which hires an external consultant for this purpose), all of them engage consultants specialized in specific types of impact studies and investigations. The consultation with key stakeholders is an extensive process, which aims at informing the public and the concerned authorities (mainly the municipality, the county administrative board, and the military) about the potential impacts of establishing a wind power plant in a specific area, receiving their inputs and suggestions and, potentially, revising the project to handle the main conflicts of interest.

Management of input providers involves coordinating civil engineering companies, turbine suppliers and grid companies, that all need access to the construction site in a specific order. The turbine delivery is especially sensitive, so any delays related to civil engineering works (e.g., roads, foundations, and crane sites), for example due to unknown geological conditions, have to be fixed without disturbing the overall time schedule.

\subsubsection{Trade-offs associated with value creation and capture}

The wind intermediaries face two main trade-offs: one input provider-related trade-off between profit margin and quality control and one client-related trade-off between profit margin and customer values such as legitimacy.

In relation to input providers, the main trade-off is linked to the intermediaries' efforts to reduce capital costs in order to increase their profit margins. This leads to pressures on input providers, which might feel forced to take shortcuts. This especially refers to civil engineering contractors, which have few means to lower costs other than reducing the amount of material put into roads and crane sites. The intermediary therefore has to check the quality of the civil engineering work carefully before turbine delivery. This incurs extra costs, since third-party inspectors have to be brought in.

In relation to clients, the main trade-off is linked to the choice of which key activities the intermediaries should perform in-house versus outsource to different input providers. By doing things in-house, the intermediaries can capture more of the created value, since there are fewer parties involved. However, by outsourcing some activities to independent and local partners other essential value dimensions can be fulfilled. Most notably, working with local 
and independent providers of some services is often required to gain legitimacy. For example, Wind B explains that during public consultations, it emphasizes the positive aspects of working with local entrepreneurs, such as new local job creation and other economic benefits for the community. Similarly, Wind A and D hire external consultants to do wind measurements and environmental assessments, because it is seen as more credible:

“In our company, we actually have experts in all areas. It's just that you can't use all the skills because you have to pick it outside the house to make it legitimate. We have environmental engineers who are very experienced and skilled, but you may have to pick someone outside who does an investigation." (Wind A)

"It is not enough that we measured the wind ourselves and made our investigation reports because an impartial consultant has to review our measurements and it not enough with one, but there should be 2-3 to review our work to say that this is OK." (Wind D)

It is noteworthy that there does not seem to be any client-related trade-offs between project quality/price and the intermediaries' profit margins. This can be explained by the economic model the intermediaries use. Since client value is measured as ROI, the price wind intermediaries can charge for a wind power share is related to the size of the investment and the projected annual electricity production. ${ }^{7}$ In order to increase this value, intermediaries have to design the projects so that they produce a lot of electricity and require as little capital investment as possible. Since intermediaries tend to retain some ownership in the projects they develop, both these measures increase their own profits. Thus, there is no apparent conflict of interest between wind power intermediaries and their clients in this respect. Coownership can also influence customer relationships positively, since it increases the intermediary's legitimacy and the clients' trust: "We are going to look each other in the eyes for many years ahead [and] they know I will do my best" (Wind G). Indeed, intermediaries that co-own projects also tend to see the adopters more as partners than as clients.

\subsection{Solar PV intermediaries}

The seven solar PV intermediaries included in this study differ in terms of how they define their main business and their value proposition. Solar A and B provide solar PV consultancy

\footnotetext{
${ }^{7}$ Intermediaries and their customers use the so-called "IP number" to determine how good an investment is. The IP number is calculated according to the formula total investment/estimated yearly production in $\mathrm{kWh}$.
} 
services and environmental consultancy services respectively. Solar C-E are specialized solar PV project developers. Finally, Solar F is a solar PV wholesaler, which buys solar panels directly from the manufacturer and sells them to electrical installation companies, and Solar G's main business is electric installations, although it also offers solar PV development services. The focus here is on the project development business, although other types of service provision will also be mentioned when it adds to the discussion. Solar PV projects tend to involve a solar project developer (often an installation company) positioned between on the one hand one client (households, housing cooperatives or companies, or diversifying companies) and on the other hand various input providers, such as suppliers of solar systems and complementary equipment (e.g. roof fixtures), government agencies supplying investment subsidies, and sub-contractors.

\subsubsection{Value creation through brokering}

The main value proposition of the solar intermediaries that develop entire projects (Solar B-E and $\mathrm{G}$ ) is the development of turnkey solar projects against a fixed fee. They take care of the entire process from site inspection, over plant configuration to an operational solar PV plant and, thus, create value for their clients by offering total solutions or, in the words of Solar D, "a carefree investment". In contrast, Solar A and F only offer part of these total solutions (as will be explained more in detail below). In addition, the solar PV developers tend to have their own "specialties" that they argue create additional value for the clients. For example, Solar A provides feasibility studies and solar project mappings, Solar B provides its own tradable green certificate meter, Solar C offers monitoring services, and Solar E has a demonstration plant where it tests different panels and mounting technologies and shows prospective clients how the technology works.

The solar intermediaries create these values mainly through two of the brokering mechanisms and the activities associated with these: transfer and coordination. Indeed, only one company (Solar F) seems to be engaged in match-making. In this context, transfer consists of technology procurement, which includes technology/supplier assessment and selection and, in some cases, stockholding. All intermediaries except Solar A help their clients choose adequate solar panels and decide which roof fixture to use. This includes configuring the plants with regard to size and capacity and involves a high degree of customization since all plants are different. For roof-top solar, the solar PV system has to be configured to suit each specific roof and match the client's electricity consumption. 
The intermediaries also place the order for the panels with the panel manufacturer or a retailer. However, they do this in slightly different ways. Solar B and G buy the equipment from wholesalers or retailers. This implies that they, for the most part, assess and evaluate both technology and suppliers per project. Wholesalers and retailers also provide support regarding plant configuration:

“... we work with large wholesalers. ... one of these has a guy who only works with solar PV and is a specialist. If you give him enough time, he will help us to calculate a job, for example how many panels we need and how we can install them." (Solar B)

In contrast, Solar C-F buy solar panels directly from the manufacturers, often in larger volumes and to their own stock. This requires more knowledge about the panels and the manufacturers (as mentioned by Solar D and F), which might explain why most of these companies only offer one or a few brands. They, thus, pre-select panel manufacturers on behalf of all clients, and while technology assessment/selection is done for each project, it is restricted to the panels the intermediaries currently have in stock. Solar F differs from the others in this group in that it is a wholesaler, which implies that it buys and stores solar panels from a selection of manufacturers and sell them to installation companies that in turn work on behalf of solar PV adopters. This includes knowledge and support with regard to plant configuration, which is especially important when the installer is inexperienced: "When they get started, we will be their main support. I hold their hand and I assist the customer at the installation site the first time" (Solar F).

Finally, Solar A assist its clients by helping them write tenders for public procurement of suppliers of turnkey systems. Similar to Solar F, it thus intermediates between the client and other diffusion intermediaries. Since tenders include specifications of the plant, this nevertheless includes elements of technology (and supplier) assessment.

Coordination includes assemblage of various inputs and management of input providers when delivering turnkey projects (Solar B-E and G). Apart from technology transfer, as described in the previous paragraphs, assemblage of inputs includes helping clients apply for building permits (from the municipality), investment subsidies (from the Swedish Energy Agency), and loans (from banks). It also includes sourcing of construction and electric installation services. Here, there are different strategies regarding how much is done in-house versus outsourced. Some solar PV intermediaries have their own electricians and builders, whereas 
others allow customers to choose among their local companies (often companies they already have a relationship with from other types of projects).

Management of input providers is mainly related to the physical installation of the plants. This requires the intermediaries to coordinate delivery of panels and other equipment from retailers/wholesalers or their own stock, internal or external providers of construction and electric installation services, and people from the local electricity grid company to connect the plant to the grid. Depending on what sourcing decision they have made, this is a more or less complex process that can involve quite a lot of different actors that have to turn up in the right order at the site.

\subsubsection{Trade-offs associated with value creation and capture}

The solar intermediaries face two main types of value creation trade-offs: a client-related trade-off between quality and profit margin and an input provider-related trade-off between different types of costs related to internal and external sourcing. In addition, they face tradeoffs related to value creation, that is between different value dimensions such as quality and price.

In relation to clients, the main trade-off concerns quality versus profit margin. The intermediaries want to offer the highest quality with regard to panels, installations, safety, etc. and therefore focus on providing one or a few premium panels. However, from the clients' perspective, quality is not necessarily the unique selling point (cf. Aspeteg and Mignon, 2019). According to the intermediaries, most clients do not understand or appreciate the finer details of, for example roof fixtures, but instead tend to ask about the plant's payback time, which implies that the price comes into focus. It, thus, becomes difficult for the intermediaries to add a satisfactory margin. According to the interviews, there are four different strategies to handle this:

1) to offer at least one slightly simpler and cheaper PV model (e.g., Solar D and F), i.e. sacrifice some value creation (quality) to be able to capture value;

2) to automatize or systematize the processes as much as possible, for example by using SMS to notify customers of the project's progression (e.g., Solar C and D), i.e. make a compromise between value creation and margin; 
3) to offer a low initial price but add additional fees for correctional and additional work to increase the margin (e.g., Solar G), i.e. avoid having to make a trade-off by "luring" the client into a deal that seems cheaper than it actually is $;^{8}$ and

4) to reject projects with too low margins, for example because of a competitive public procurement process in which some of the competitors might be using the previous strategy (e.g., Solar G), i.e. refuse to compromise.

In relation to input providers, there are trade-offs with regard to the choice to buy solar panels directly from the manufacturers or via a wholesaler or retailer. On the one hand, direct purchasing sacrifices some degree of efficiency, since it ties up capital and perhaps also requires taking loans (and paying interest) to buy the equipment. It also requires more personnel. On the other hand, it cuts out the middle man (the wholesaler or retailer) and, thus, raises the margin. Moreover, when external input providers are used, this can incur an extra cost for quality controls.

The sourcing decision also creates interesting trade-offs between different types of value creation. Some of the intermediaries that stock equipment do it to make sure they can deliver panels to their customers in a timely fashion, and some of those who buy from retailers or wholesalers want to make sure the customers can benefit from recent technology improvements and cost reductions. There are also other value creation-related trade-offs. Because of the tight margins, intermediaries have to choose between, on the one hand, keeping prices down by using standardization and automatization and, on the other hand, building and maintaining a close customer relationship. In addition, quality can come into conflict with the client's freedom of choice. To uphold high quality, intermediaries want to have few supplier relationships and they therefore do not offer more than a few brands. In effect, they select the technology on behalf of the adopters and, thus, limit their choices. In some cases, this implies that the intermediary even has to turn a customer down if it requests a specific solar panel brand (as mentioned by Solar D). Another example of this trade-off is that some intermediaries use internal installers (or work with long-term partners) to ensure installation quality, whereas others prioritize their clients' freedom to choose a local builder or electrician they know and trust.

\footnotetext{
${ }^{8}$ The companies have different opinions about this strategy. Solar G considers it necessary to add charges for such work to reach profitability, whereas several of the other solar PV intermediaries think that this kind of behaviour is annoying.
} 


\subsection{Summary and comparative analysis}

In this section, the main similarities and differences of the findings from the two technologies with regard to brokering and trade-offs are discussed. The overall findings of the study in relation to the analytical are summarized in Figure 3.

\subsubsection{Value creation through brokering}

To begin with, it is interesting to note that although the diffusion intermediaries in this study are involved with renewables, their business models for the most part do not correspond to what the literature has described as "sustainable" (hybrid) business models, that is business models that aim at simultaneously creating economic and environmental and/or societal value (cf., e.g., Bocken et al., 2014). Instead, they are focused mainly on achieving traditional economic values for their clients, such as return on investment (wind) or short pay-back time (solar). This also distinguishes them from transition intermediaries, which tend to pursue sustainability-oriented goals or at least aim at some kind of system-level change (Kivimaa et al., 2019a).

In general, wind power and solar PV intermediaries offer similar types of value propositions, that is they provide total solutions in the form of turnkey wind or solar PV projects (although some solar intermediaries offer more specialized services). The main difference is that wind power intermediaries sell shares and, thus, an estimated return on investment, while solar PV intermediaries sell the actual plant and the services required to put it in place.

With regard to brokering, wind and solar intermediaries create these values mainly in the form of coordination of different input providers, with technology transfer as an important part of the offer. In this context, transfer mainly includes technology procurement, through which technology is transferred from wholesalers, retailers, or manufacturers to the clients. This involves an assessment and selection of technologies and suppliers and, in some solar cases, stockholding of technical equipment. The procurement process seems more competitive in wind than in solar. In wind, most intermediaries use open tenders, whereas solar intermediaries tend to prioritize longer-term relationships with one or a few panel manufacturers, retailers, or wholesalers. Several of them also buy to stock rather than per project (as in wind). In both fields, the intermediaries tend to choose technology manufacturers and other input providers on behalf of the clients. 
In both fields, coordination involves two main intermediation activities: assemblage of inputs from various parties in different stages of the project (e.g., technology, permits, and funding) and management of input providers in the installation phase. These activities are rather standardized and span the entire implementation process. The main difference between the technologies is that coordination is much more complicated in wind than in solar, because of the higher project complexity. Solar projects mainly require coordination within the supply chain, for example between technology suppliers and installers. In contrast, wind power projects involve a much broader set of stakeholders, including supply chain actors as well as experts and service providers, authorities, and the general public. Moreover, wind power coordination is not only required for the project as a whole, but also for each step of the process, including environmental impact assessment, permitting, and construction.

In comparison with previous literature on innovation intermediaries in general, and diffusion intermediaries in particular, two main things stand out. First, there is very little evidence of match-making in our data. Indeed, Solar F is the one company that mentioned connecting different actors to each other (in that case adopters to installation companies). This is rather surprising, considering how important the match-making brokering mechanism seems to be for technology development (cf., e.g., Howells, 2006; Katzy et al., 2013; Sieg et al., 2010). However, this finding supports previous claims that technology development and diffusion are related but different processes that involve partly different actors and activities (Bergek, 2019b). Match-making has been observed also in a diffusion context (e.g., Dicecca et al., 2016; Poncet et al., 2010), but those studies mostly concerned practices and simple technologies. The higher complexity of wind power and solar PV might explain why direct contact between adopters and input providers is less common.

Second, coordination stands out as much more important than in previous literature. Some previous studies have indicated that innovation intermediaries can act as process managers (Klerkx and Leeuwis, 2009) or arbitrators (e.g., managing conflicts) (Johnson, 2008), or handle challenges originating in different spheres (Benouniche et al., 2016; Mignon and Bergek, 2016). However, this study shows that coordination can concern many different input providers and also extend well beyond the supply chain, for example to government bodies and the general public.

Taken together, these findings confirm that diffusion intermediaries play a different role in the ecology of intermediaries that exist around an emerging sustainable innovation (Kivimaa et 
al., 2019a) than either development-oriented innovation intermediaries or transition intermediaries.

\subsubsection{Trade-offs related to value creation and value capture}

As expected, trade-offs related to value capture exist in both fields, although they are somewhat more prominent in solar PV. This especially refers to client-related trade-offs, where the quality-margin trade-off emphasized in solar PV hardly exists in wind power. Due to the close connection between the clients' ROI and the intermediaries' profits, there is no real conflict of interest between the two parties. However, wind power intermediaries still experience a client-related trade-off between profit margin and legitimacy, which is related to the extra cost of engaging external input providers in environmental impact assessments.

In both fields, there are similar input provider-related trade-offs that are connected to sourcing decisions. Keeping activities in-house is positive from a value capture point of view, since there are fewer parties to share the created value with, as well as less need for quality controls of externally sourced products and services. However, in-house activities can sometimes become rather costly, with regard to both financial resources (e.g. capital costs for keeping a stock of equipment) and human resources (personnel costs). Which strategy creates the highest margin is, therefore, not self-evident. This might explain why solar intermediaries choose different sourcing strategies.

In relation to previous literature, these findings emphasize how difficult - not to say impossible - it is to achieve win-win solutions that satisfy all stakeholders (cf. Hahn et al., 2010). Although most of the diffusion intermediaries use various strategies to handle tradeoffs, such as that between margin and quality, there are clearly limits to how much profitoriented intermediaries can prioritize their clients over their own self-interest (cf. Klerkx et al., 2015). Moreover, trade-offs between profit margin and quality or legitimacy might create conflicts of interest between the individual goals of the diffusion intermediaries and policy goals related to innovation diffusion and sustainability transitions (cf. Klerkx and Leeuwis, 2008a).

The analysis also shows that there are trade-offs between different types of customer values, which we did not foresee in our analytical framework. This was mostly noticed in solar PV, where there were trade-offs between quality and price; quality and freedom of choice; timely delivery and freedom of choice; and timely delivery and access to the latest technology. In 
wind, the main customer value is the ROI of the project, which leaves less room for value trade-offs. Nevertheless, in both fields the insourcing-outsourcing decision discussed above involves a perceived trade-off between, on the one hand, the higher control over project quality associated with internal sourcing and, on the other hand, the legitimacy, trust, and credibility resulting from the involvement of independent and local external partners. In contrast to previous literature, which emphasizes value trade-offs between different sustainability dimensions (cf. Brennan and Tennant, 2018), these trade-offs are related to the intermediaries' unique value propositions and, thus, can have a direct impact on their competitive advantage and economic sustainability.

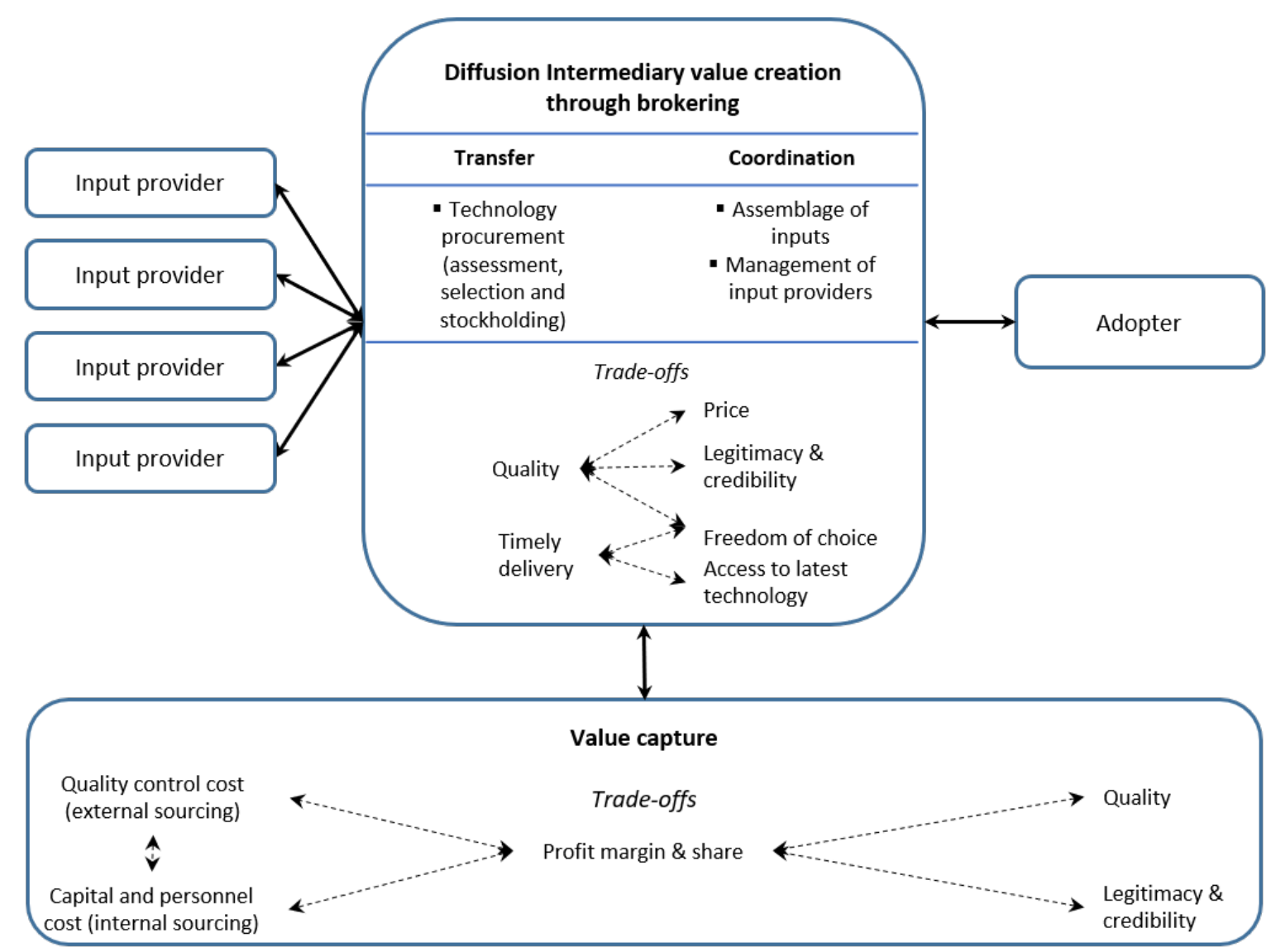

Figure 3: Graphical summary of conclusions.

\section{Conclusions and implications}

\subsection{Conclusions}

The starting point of this paper was a lack of attention in previous literature to innovation intermediaries that are located downstream in the supply chain and act as brokers between technology adopters and the providers of resources needed to adopt and implement a 
technology that is available "off-the-shelf", i.e. so-called "diffusion intermediaries". In particular, we noted that although these actors could potentially improve the rate and quality of implementation of sustainable innovations and advance sustainability transitions, there is limited knowledge about the brokering mechanisms through which they create value for their clients and other stakeholders and about the trade-offs that profit-driven diffusion intermediaries face in relation to value creation and capture.

Against this background, the purpose of the paper was to investigate through which mechanisms diffusion intermediaries, as brokers, create value for adopters of sustainable innovations and what conflicts of interests and trade-offs they face in relation to value capture. For that purpose, we studied 14 private intermediaries working with solar PV or wind power technologies in Sweden.

The first research question was what types of brokering mechanisms value creation by diffusion intermediaries is based on and what intermediation activities intermediaries carry out as part of those mechanisms. The analysis showed that diffusion intermediaries in both wind power and solar PV create value mainly through transfer and coordination. Transfer refers mainly to technology procurement and includes technology and supplier assessment/selection and, in some cases, stockholding of technical equipment (e.g. solar panels). Coordination includes intermediation activities such as input assemblage (e.g. coordination of technology procurement, contract negotiations, permit application processes, and subsidy applications) and management of input providers (e.g. synchronizing suppliers and contractors at the implementation site). In this regard, there were more similarities than differences between the two technologies. The main difference was that wind power coordination involves a broader set of actors than solar PV coordination and is needed in several steps of the process. Compared with previous literature on innovation and transition intermediaries, which mainly emphasizes the match-making brokering mechanism and focuses on sustainability goals and system-level change respectively, these findings highlight the unique role diffusion intermediaries play in the ecologies of intermediaries that exist around emerging sustainable innovations (Kivimaa et al., 2019a).

The second research question concerned the value capture trade-offs diffusion intermediaries make in relation to adopters and input providers. The analysis showed that such trade-offs exist in both fields. Client-related trade-offs refer to compromises between the intermediaries' profit margins and customer values such as quality (mainly solar) and legitimacy (mainly 
wind). Although most of the intermediaries have strategies to handle this, and in many cases also prioritize clients over margins, there are limits to how much profit-oriented intermediaries can prioritize their clients over their own self-interest (cf. Klerkx et al., 2015). Input-provider related trade-offs are for the most part connected to insourcing-outsourcing decisions, where different strategies come with different types of costs and imply different division of value between stakeholders. In addition to the expected trade-offs, the analysis also revealed trade-offs between different value creation dimensions, especially in solar PV. These trade-offs concerned, for example, compromises between quality and price, between quality and legitimacy, and between timely delivery and freedom of choice. In both fields, some of these trade-offs were related to the choice between internal and external sourcing, where compromises had to be made between project quality and trust, credibility and legitimacy considerations. These findings emphasize the challenges diffusion intermediaries need to handle to achieve long term economic sustainability. They also put the potential impact of diffusion intermediaries on sustainability transitions in new perspective by highlighting potential conflicts of interest between intermediaries' self-interests, the quality of individual adoption projects and the rate and quality of the overall diffusion process.

\subsection{Implications}

The findings of this study have implications for diffusion intermediaries, policy makers, and future research.

Diffusion intermediaries should to a higher degree formulate their business models in terms of brokering rather than general service provision, in order to highlight their unique value proposition compared with technology suppliers and other actors. This might enable them to better communicate the values they create to clients and policy makers. With regard to tradeoffs, they should consider the client- and input provider-related value capture trade-offs inherent in different types of business model choices. In addition, they need to decide which values they want to create, and which values they are willing to sacrifice, if different values come into conflict with each other. Such decisions should be clearly communicated to the clients, to enable them to make informed choices. The price-quality trade-off is of particular concern, since our study also shows that reputation plays an important role as a channel to new customers. Compromising quality to attract cost-oriented customers or manipulating them by offering a low initial cost and then charging for additional work are therefore probably not sustainable strategies in the long run. As both cases show, working with 
independent and local partners might be a good strategy to gain the customers' trust. However, in order to handle potential value creation and value capture trade-offs related to external sourcing, training of partners (e.g. builders and electricians in the solar PV field) could be needed for such a strategy to work. In the more immature solar PV field, the solar PV intermediaries might have to "run in packs" to collaboratively strengthen the knowledge infrastructure (cf. Van de Ven, 2005). Solar PV intermediaries could also try to learn from wind power intermediaries, which have been in business longer and have overcome many of the problems that are now experienced in the solar PV field.

Policy makers need to consider the important values diffusion intermediaries create through brokering, not only for individual customers and projects, but also for the diffusion process as a whole. They could, thus, be used to a higher extent as an instrument to increase the rate and quality renewable electricity project implementation. This could be an important complement to existing instruments that support technology suppliers and incentivize adopters through investment subsidies or feed-in tariffs, especially considering that diffusion intermediaries act in-between these parties. Policy initiatives to create conditions for diffusion intermediaries to enact different types of brokering mechanisms could therefore have large effects on the diffusion of sustainable innovations. In addition, diffusion intermediaries have accumulated knowledge, experience and contacts that could make them valuable collaboration partners for policy makers. In particular, diffusion intermediaries can reach many different stakeholders and can therefore play an important role in legitimizing and spreading new technologies, methods, and standards as well as implementing new regulations. However, the identified trade-offs imply that an increased involvement of intermediaries will not necessarily result in higher-quality projects. Some intermediaries might, for example, choose to compromise project quality to promote their own value capture, especially in the solar PV field where there is still quite a lot of confusion with regard to what different intermediaries have to offer (Palm, 2018). Some kind of certification scheme might therefore be needed to help potential adopters navigate this expanding ecology of intermediaries. In addition, the trade-off between quality and legitimacy points at a potential contradiction between increasing the rate and the quality of adoption. In order to achieve a higher adoption rate, there has to be acceptance for new projects. To achieve this, diffusion intermediaries might have to let go of some control and bring in external actors with local anchoring and/or high credibility - perhaps at the expense of quality. This implies that policy makers need to decide whether the number of 
projects or their quality is more important when designing policies that involve diffusion intermediaries.

With regard to researchers, this paper has resulted in new knowledge about the unique role diffusion intermediaries play in an ecology of intermediaries and about the trade-offs associated with value creation and capture in this context. However, several issues could be investigated further. First, considering the importance of coordination, future research should investigate further what this mechanism includes in different contexts. Deep longitudinal case studies of both development- and diffusion-oriented innovation intermediaries would provide a more detailed understanding of the activities and functions associated with coordination. Such studies should also cover other fields than renewable energy technology and other countries than Sweden to improve the generalizability of the results. Second, the difference in maturity between the two fields implies that it may be worthwhile to study the emergence and further development of the diffusion intermediary industry in different technological fields in order to identify common patterns, challenges, and pitfalls as well as strategies for achieving a successful transformation into a well-functioning support system for technology adoption and diffusion. Third, the identified trade-offs between different value dimensions raise interesting questions about how private, non-neutral diffusion intermediaries influence overall diffusion and transition processes. One limitation of this study is that it has not been able to fully demonstrate the consequences of the identified brokering mechanisms and trade-offs on sustainability transitions. Further studies could show whether the diffusion intermediaries' strategic choices are in line with societal goals and missions or if there is a risk that they will create unforeseen system-level barriers to further diffusion.

\section{Acknowledgements}

Funding from the Swedish Energy Agency (grant number 40642-1) is gratefully acknowledged. The funder has not been involved in study design, in the collection, analysis and interpretation of data, in the writing of the article, or in the decision to submit the article for publication.

\section{References}

Abbate, T., Coppolino, R., Schiavone, F., 2013. Linking Entities in Knowledge Transfer: The Innovation Intermediaries. Journal of the Knowledge Economy 4(3), 233-243. 
Agogué, M., Berthet, E., Fredberg, T., Le Masson, P., Segrestin, B., Stoetzel, M., Wiener, M., Yström, A., 2017. Explicating the role of innovation intermediaries in the "unknown": a contingency approach. Journal of Strategy and Management 10(1), 19-39.

Aspeteg, J., Mignon, I., 2019. Intermediation services and adopter expectations and demands during the implementation of renewable electricity innovation - match or mismatch? Journal of Cleaner Production.

Baden-Fuller, C., Mangematin, V., 2013. Business models: A challenging agenda. Strategic Organization 11(4), 418-427.

Benouniche, M., Errahj, M., Kuper, M., 2016. The Seductive Power of an Innovation: Enrolling Non-conventional Actors in a Drip Irrigation Community in Morocco. The Journal of Agricultural Education and Extension 22(1), 61-79.

Bergek, A., 2019a. Diffusion intermediaries: a taxonomy based on renewable electricity technology in Sweden. accepted for publication in Environmental Innovation and Societal Transitions.

Bergek, A., 2019b. Technological Innovation Systems: a review of recent findings and suggestions for future research, in: Boons, F., McMeekin, A. (Eds.), Handbook of Sustainable Innovatino. Edvard Elgar Publishing, Cheltenham.

Bergek, A., Hekkert, M., Jacobsson, S., 2008. Functions in innovation systems: A framework for analysing energy system dynamics and identifying goals for system-building activities by entrepreneurs and policy makers, in: Foxon, T.J., Köhler, J., Oughton, C. (Eds.), Innovation for a Low Carbon Economy: Economic, Institutional and Management Approaches. Edward Elgar, Cheltenham, pp. 79-111.

Bergek, A., Mignon, I., 2017. Motives to adopt renewable electricity technologies: Evidence from Sweden. Energy Policy 106, 547-559.

Bergek, A., Mignon, I., Sundberg, G., 2013. Who invests in renewable electricity production? Empirical evidence and suggestions for further research. Energy Policy 56, 568-581.

Bessant, J., Rush, H., 1995. Building bridges for innovation: the role of consultants in technology transfer. Research Policy 24(1), 97-114.

Bocken, N.M.P., Short, S.W., Rana, P., Evans, S., 2014. A literature and practice review to develop sustainable business model archetypes. Journal of Cleaner Production 65, 42-56.

Boons, F., Lüdeke-Freund, F., 2013. Business models for sustainable innovation: state-of-theart and steps towards a research agenda. Journal of Cleaner Production 45, 9-19.

Brennan, G., Tennant, M., 2018. Sustainable value and trade-offs: Exploring situational logics and power relations in a UK brewery's malt supply network business model. Business Strategy and the Environment 27(5), 621-630.

Bush, R.E., Bale, C.S.E., Powell, M., Gouldson, A., Taylor, P.G., Gale, W.F., 2017. The role of intermediaries in low carbon transitions - Empowering innovations to unlock district heating in the UK. Journal of Cleaner Production 148, 137-147.

Caiazza, R., Volpe, T., 2017. Innovation and its diffusion: process, actors and actions.

Technology Analysis \& Strategic Management 29(2), 181-189.

Cantner, U., Meder, A., Wolf, T., 2011. Success and failure of firms' innovation cooperations: The role of intermediaries and reciprocity*. Papers in Regional Science 90(2), 313-329.

Chesbrough, H., 2006. Open Business Models: How To Thrive In The New Innovation Landscape. Harvard Business Press, Boston (MA).

Clauss, T., 2017. Measuring business model innovation: conceptualization, scale development, and proof of performance. R\&D Management 47(3), 385-403.

Colombo, G., Dell'Era, C., Frattini, F., 2015. Exploring the contribution of innovation intermediaries to the new product development (NPD) process: a typology and an empirical study. R\&D Management 45(2), 126-146. 
Dahlander, L., Gann, D.M., 2010. How open is innovation? Research Policy 39(6), 699-709. Dicecca, R., Pascucci, S., Contò, F., 2016. Understanding reconfiguration pathways of agrifood value chains for smallholder farmers. British Food Journal 118(8), 1857-1882.

Edler, J., Yeow, J., 2016. Connecting demand and supply: The role of intermediation in public procurement of innovation. Research Policy 45(2), 414-426.

Flyvbjerg, B., 2006. Five Misunderstandings About Case-Study Research. Qualitative Inquiry 12(2), 219-245.

Freeman, R.E., 2010. Managing for Stakeholders: Trade-offs or Value Creation. J Bus Ethics 96, 7-9.

Geels, F.W., 2011. The multi-level perspective on sustainability transitions: Responses to seven criticisms. Environmental Innovation and Societal Transitions 1(1), 24-40.

Gibbs, D., O'Neill, K., 2014. Rethinking Sociotechnical Transitions and Green

Entrepreneurship: The Potential for Transformative Change in the Green Building Sector.

Environment and Planning A 46(5), 1088-1107.

Gliedt, T., Hoicka, C.E., Jackson, N., 2018. Innovation intermediaries accelerating environmental sustainability transitions. Journal of Cleaner Production 174, 1247-1261. Hahn, T., Figge, F., Pinkse, J., Preuss, L., 2010. Trade-offs in corporate sustainability: you can't have your cake and eat it. Business Strategy and the Environment 19(4), 217-229. Hargadon, A., Sutton, R.I., 1997. Technology Brokering and Innovation in a Product Development Firm. Administrative Science Quarterly 42(4), 716-749.

Hellsmark, H., Jacobsson, S., 2009. Opportunities for and limits to Academics as System builders-The case of realizing the potential of gasified biomass in Austria. Energy Policy 37(12), 5597-5611.

Holzmann, T., Sailer, K., Katzy, B.R., 2014. Matchmaking as multi-sided market for open innovation. Technology Analysis \& Strategic Management 26(6), 601-615.

Howells, J., 2006. Intermediation and the role of intermediaries in innovation. Research Policy 35(5), 715-728.

Håkanson, L., Caessens, P., MacAulay, S., 2011. InnovationXchange: A case study in innovation intermediation. Innovation 13(2), 261-274.

Jansen, H., 2010. The logic of qualitative survey research and its position in the field of social research methods. Forum Qualitative Sozialforschung 11(2), Art 11.

Janssen, W., Bouwman, H., Buuren, R.v., Haaker, T., 2014. An organizational competence model for innovation intermediaries. European Journal of Innovation Management 17(1), 224.

Johnson, W.H.A., 2008. Roles, resources and benefits of intermediate organizations supporting triple helix collaborative R\&amp;D: The case of Precarn. Technovation 28(8), 495-505.

Kanda, W., Hjelm, O., Clausen, J., Bienkowska, D., 2018. Roles of intermediaries in supporting eco-innovation. Journal of Cleaner Production 205, 1006-1016.

Karakaya, E., Nuur, C., Hidalgo, A., 2016. Business model challenge: Lessons from a local solar company. Renewable Energy 85, 1026-1035.

Katzy, B., Turgut, E., Holzmann, T., Sailer, K., 2013. Innovation intermediaries: a process view on open innovation coordination. Technology Analysis \& Strategic Management 25(3), 295-309.

Kivimaa, P., 2014. Government-affiliated intermediary organisations as actors in system-level transitions. Research Policy 43(8), 1370-1380.

Kivimaa, P., Boon, W., Hyysalo, S., Klerkx, L., 2019a. Towards a typology of intermediaries in sustainability transitions: A systematic review and a research agenda. Research Policy 48(4), 1062-1075. 
Kivimaa, P., Hyysalo, S., Boon, W., Klerkx, L., Martiskainen, M., Schot, J., 2019b. Passing the baton: How intermediaries advance sustainability transitions in different phases.

Environmental Innovation and Societal Transitions.

Klerkx, L., Álvarez, R., Campusano, R., 2015. The emergence and functioning of innovation intermediaries in maturing innovation systems: the case of Chile. Innovation and Development 5(1), 73-91.

Klerkx, L., Leeuwis, C., 2008a. Balancing multiple interests: Embedding innovation intermediation in the agricultural knowledge infrastructure. Technovation 28(6), 364-378.

Klerkx, L., Leeuwis, C., 2008b. Matching demand and supply in the agricultural knowledge infrastructure: Experiences with innovation intermediaries. Food Policy 33(3), 260-276.

Klerkx, L., Leeuwis, C., 2009. Establishment and embedding of innovation brokers at different innovation system levels: Insights from the Dutch agricultural sector. Technological Forecasting and Social Change 76(6), 849-860.

Küçüksayraç, E., Keskin, D., Brezet, H., 2015. Intermediaries and innovation support in the design for sustainability field: cases from the Netherlands, Turkey and the United Kingdom. Journal of Cleaner Production 101, 38-48.

Martiskainen, M., Kivimaa, P., 2018. Creating innovative zero carbon homes in the United Kingdom - Intermediaries and champions in building projects. Environmental Innovation and Societal Transitions 26, 15-31.

Matschoss, K., Heiskanen, E., 2017. Making it experimental in several ways: The work of intermediaries in raising the ambition level in local climate initiatives. Journal of Cleaner Production 169, 85-93.

Mignon, I., 2016. Intermediary-user collaboration during the innovation implementation process. Technology Analysis \& Strategic Management, 1-15.

Mignon, I., Bergek, A., 2016. System- and actor-level challenges for diffusion of renewable electricity technologies: an international comparison. Journal of Cleaner Production 128, 105115.

Mignon, I., Kanda, W., 2018. A typology of intermediary organizations and their impact on sustainability transition policies. Environmental Innovation and Societal Transitions 29, 100113.

Mizik, N., Jacobson, R., 2003. Trading off between Value Creation and Value Appropriation: The Financial Implications of Shifts in Strategic Emphasis. Journal of Marketing 67(1), 6376.

Muñoz, P., Cohen, B., 2018. Sustainable Entrepreneurship Research: Taking Stock and looking ahead. Business Strategy and the Environment 27(3), 300-322.

Nilsson, M., Sia-Ljungström, C., 2013. The role of innovation intermediaries in innovation systems, in: Rickert, U., Schiefer, G. (Eds.), Proceedings in system dynamics and innovation in food networks 2013, 7th International European Forum on System Dynamics and Innovation in Food Networks. Innsbruck-Igls.

Osterwalder, A., Pigneur, Y., 2010. Business Model Generation. John Wiley \& Sons, Hoboken (NJ).

Osterwalder, A., Pigneur, Y., Tucci, C.L., 2005. Clarifying Business Models: Origins, Present, and Future of the Concept. Communications of AIS 15.

Owen, A., Mitchell, G., Gouldson, A., 2014. Unseen influence-The role of low carbon retrofit advisers and installers in the adoption and use of domestic energy technology. Energy Policy 73, 169-179.

Palm, A., 2015. An emerging innovation system for deployment of building-sited solar photovoltaics in Sweden. Environmental Innovation and Societal Transitions 15, 140-157. Palm, J., 2018. Household installation of solar panels - Motives and barriers in a 10-year perspective. Energy Policy 113, 1-8. 
Parag, Y., Janda, K.B., 2014. More than filler: Middle actors and socio-technical change in the energy system from the "middle-out". Energy Research \& Social Science 3(Supplement C), 102-112.

Poncet, J., Kuper, M., Chiche, J., 2010. Wandering off the paths of planned innovation: The role of formal and informal intermediaries in a large-scale irrigation scheme in Morocco.

Agricultural Systems 103(4), 171-179.

Porter, M.E., 1980. Competitive strategy: Techniques for analyzing industries and competitors. The Free Press, New York.

Rogers, E.M., 2003. Diffusion of Innovations ( $5^{\text {th }}$ ed.), 5th ed. The Free Press, New York. Seawright, J., Gerring, J., 2008. Case Selection Techniques in Case Study Research. Political Research Quarterly 61(2), 294-308.

Sieg, J.H., Wallin, M.W., Von Krogh, G., 2010. Managerial challenges in open innovation: a study of innovation intermediation in the chemical industry. R\&D Management 40(3), 281291.

Smith, A., 2003. Transforming technological regimes for sustainable development: A role for alternative technology niches? Science and Public Policy 30(2), 127-135.

Spiro, E.S., Acton, R.M., Butts, C.T., 2013. Extended structures of mediation: Re-examining brokerage in dynamic networks. Social Networks 35(1), 130-143.

Stankiewicz, R., 1995. The role of the science and technology infrastructure in the development and diffusion of industrial automation in Sweden, in: Carlsson, B. (Ed.) Technological Systems and Economic Performance: The Case of Factory Automation. Kluwer Academic Publishers, Dordrecht, pp. 165-210.

Stewart, J., Hyysalo, S., 2008. Intermediaries, users and social learning in technological innovation. International Journal of Innovation Management 12(03), 295-325.

Strupeit, L., Palm, A., 2016. Overcoming barriers to renewable energy diffusion: business models for customer-sited solar photovoltaics in Japan, Germany and the United States. Journal of Cleaner Production 123, 124-136.

Theodorakopoulos, N., Bennett, D., Sánchez Preciado, D.J., 2014. Intermediation for technology diffusion and user innovation in a developing rural economy: a social learning perspective. Entrepreneurship and Regional Development 26, 645-662.

Van de Ven, A.H., 2005. Running in Packs to Develop Knowledge-Intensive Technologies. MIS Quarterly 29(2), 365-378.

Winch, G.M., Courtney, R., 2007. The Organization of Innovation Brokers: An International Review. Technology Analysis \& Strategic Management 19(6), 747-763.

Von Nell, P.S., Lichtenthaler, U., 2011. Innovation intermediaries: a case study of yet2.com. International Journal of Technology Intelligence and Planning 7(3), 215-231.

Yin, R.K., 1984. Case study research: Designs and Methods. Sage Publications, Beverly Hills, CA.

Zott, C., Amit, R., 2010. Business Model Design: An Activity System Perspective. Long Range Planning 43(2-3), 216-226.

Zott, C., Amit, R., Massa, L., 2011. The Business Model: Recent Developments and Future Research. Journal of Management 37(4), 1019-1042.

Överholm, H., 2017. Alliance formation by intermediary ventures in the solar service industry: implications for product-service systems research. Journal of Cleaner Production 140, Part 1, 288-298. 


\section{Appendix A: Main interview areas and question topics}

\begin{tabular}{|c|c|c|}
\hline Area & Sub-area & Question topics \\
\hline \multirow[t]{13}{*}{$\begin{array}{l}\text { Business } \\
\text { model }\end{array}$} & \multirow[t]{3}{*}{$\begin{array}{l}\text { Value } \\
\text { proposition }\end{array}$} & $\begin{array}{l}\text { What does the company do within renewable energy technology? How does the company support the adopters in their adoption process } \\
\text { more generally? In which phases of a project is the company involved? }\end{array}$ \\
\hline & & What services does the company provide? Are they standardized or customized? \\
\hline & & What makes customers use an intermediary rather than do it themselves? What makes them choose the company over its competitors? \\
\hline & $\begin{array}{l}\text { Customer } \\
\text { segments }\end{array}$ & What types of customers does the company focus on? Do the value propositions differ between customer types? \\
\hline & \multirow{2}{*}{$\begin{array}{l}\text { Customer } \\
\text { relationships }\end{array}$} & What type of relationship does the company have with its customers (transaction or close relationship, one-time deal or repeat buying)? \\
\hline & & How involved is the customer in different phases of a project? \\
\hline & Channels & $\begin{array}{l}\text { Who typically initiates the contact? To what extent and how does the company maintain contact with the customer throughout the project } \\
\text { and afterwards? }\end{array}$ \\
\hline & \multirow{2}{*}{$\begin{array}{l}\text { Key activities \& } \\
\text { partners }\end{array}$} & What are the main activities involved in a project? \\
\hline & & What activities does the company perform itself and what activities does it outsource to its partners? Why? Who are the main partners? \\
\hline & \multirow[t]{2}{*}{ Key resources } & What are the company's most important resources? \\
\hline & & How do the customers finance their projects? Is the company involved in funding in some phase? \\
\hline & Cost structure & What are the most important costs of a project and of the company as a whole? \\
\hline & $\begin{array}{l}\text { Revenue } \\
\text { streams }\end{array}$ & How and when in the project does the company get paid? Are there different economic models? \\
\hline \multirow{7}{*}{$\begin{array}{l}\text { Challenges } \\
\text { and trade-offs }\end{array}$} & \multirow[t]{2}{*}{ Success criteria } & What characterizes a "good" project? What formal and informal criteria are used to evaluate projects? \\
\hline & & When are customers satisfied with a project? When is the company satisfied? \\
\hline & Trade-offs & What tradeoffs between different criteria or opinions does the company have to make? What are the main considerations in such cases? \\
\hline & \multirow{2}{*}{$\begin{array}{l}\text { Conflicts of } \\
\text { interest }\end{array}$} & What type of conflicts arise between different stakeholders and within the company? Which of these are generic to all projects? \\
\hline & & What strategies has the company developed to handle conflicts of interest? \\
\hline & \multirow[t]{2}{*}{ Challenges } & What are the main challenges for projects within renewable energy? What does the company do to handle these challenges? \\
\hline & & What is the main challenges with regard to the company's role in the projects? \\
\hline
\end{tabular}

Note: More specific questions and follow-up questions were used within each question topic to stimulate the interviewee to elaborate more on each topic. 


\section{Appendix B: Summary of wind and solar diffusion intermediaries' business models}

Table B1. Wind intermediaries' business models

\begin{tabular}{|c|c|c|c|c|c|c|c|}
\hline & Wind $\mathrm{A}$ & Wind B & Wind C & Wind D & Wind $\mathrm{E}$ & Wind $\mathrm{F}$ & Wind $\mathrm{G}$ \\
\hline $\begin{array}{l}\text { Value } \\
\text { proposition }\end{array}$ & $\begin{array}{l}\text { Project development; } \\
\text { develops and manages } \\
\text { wind power in good } \\
\text { locations }\end{array}$ & $\begin{array}{l}\text { Project } \\
\text { development; } \\
\text { finances and } \\
\text { manages wind } \\
\text { power plants. }\end{array}$ & $\begin{array}{l}\text { Project } \\
\text { development }\end{array}$ & $\begin{array}{l}\text { Project } \\
\text { development; } \\
\text { quality and } \\
\text { knowledge } \\
\text { through all } \\
\text { phases of the } \\
\text { project. }\end{array}$ & $\begin{array}{l}\text { Electricity } \\
\text { production and } \\
\text { sales. } \\
\text { Development, } \\
\text { ownership and } \\
\text { management of } \\
\text { plants; sells } \\
\text { shares to other } \\
\text { companies. }\end{array}$ & $\begin{array}{l}\text { Electricity } \\
\text { production. } \\
\text { Development and } \\
\text { management of } \\
\text { plants for external } \\
\text { investors; controls } \\
\text { the whole value } \\
\text { chain. }\end{array}$ & $\begin{array}{l}\text { Electricity } \\
\text { production and sales; } \\
\text { to enable the } \\
\text { transition to a } \\
\text { sustainable energy } \\
\text { system. } \\
\text { Project development; } \\
\text { always part-owner in } \\
\text { the plant. }\end{array}$ \\
\hline $\begin{array}{l}\text { Project } \\
\text { locations and } \\
\text { customer } \\
\text { segments }\end{array}$ & $\begin{array}{l}\text { Sweden, Norway, } \\
\text { Finland, USA, Estonia } \\
\text { and Latvia. } \\
\text { Foreign asset managers, } \\
\text { large companies, energy } \\
\text { companies, farmers, } \\
\text { forest owners. }\end{array}$ & $\begin{array}{l}\text { Nordic countries. } \\
\text { Large companies, } \\
\text { municipalities, } \\
\text { housing } \\
\text { associations, } \\
\text { energy } \\
\text { companies. }\end{array}$ & $\begin{array}{l}\text { Sweden and } \\
\text { China. } \\
\text { Energy companies } \\
\text { and pension funds. }\end{array}$ & $\begin{array}{l}\text { Sweden } \\
\text { Foreign } \\
\text { investors, } \\
\text { pension funds, } \\
\text { large companies. }\end{array}$ & $\begin{array}{l}\text { Sweden, Norway } \\
\text { and Finland. } \\
\text { Electricity } \\
\text { companies and } \\
\text { land owners. }\end{array}$ & $\begin{array}{l}\text { Sweden } \\
\text { Electricity } \\
\text { consumers } \\
\text { (households and } \\
\text { organizations) - } \\
\text { directly or via } \\
\text { Nordpool exchange; } \\
\text { wind farm owners } \\
\text { (farm management). }\end{array}$ & $\begin{array}{l}\text { Sweden (but not } \\
\text { home region, } \\
\text { because of } \\
\text { competition with } \\
\text { parent company). } \\
\text { Customers with a lot } \\
\text { of capital, i.e. } \\
\text { pension funds, } \\
\text { energy companies } \\
\text { (including parent } \\
\text { company) and } \\
\text { housing companies. }\end{array}$ \\
\hline $\begin{array}{l}\text { Customer } \\
\text { relationships }\end{array}$ & $\begin{array}{l}\text { Difficult to have close } \\
\text { relationship with } \\
\text { foreign customers. } \\
\text { Large companies want } \\
\text { to do the financial } \\
\text { calculations themselves } \\
\text { based; supplies cost } \\
\text { estimates with }\end{array}$ & $\begin{array}{l}\text { Emphasize that } \\
\text { customers have } \\
\text { different needs. } \\
\text { Important to keep } \\
\text { landowners } \\
\text { updated (they also } \\
\text { have priority to }\end{array}$ & $\begin{array}{l}\text { Sees the customer } \\
\text { as a partner; } \\
\text { foreign investors } \\
\text { want information } \\
\text { about how the } \\
\text { Swedish system } \\
\text { works. }\end{array}$ & $\begin{array}{l}\text { Parent company } \\
\text { deals with } \\
\text { customer } \\
\text { relationships. }\end{array}$ & Co-owners. & Co-owners/partners. & $\begin{array}{l}\text { Investors are passive } \\
\text { (do not want } \\
\text { control). } \\
\text { Direct contact with } \\
\text { all owners. } \\
\text { Lasting relationship } \\
\text { to customers due to }\end{array}$ \\
\hline
\end{tabular}




\begin{tabular}{|c|c|c|c|c|c|c|c|}
\hline & $\begin{array}{l}\text { assumptions that they } \\
\text { can work with. }\end{array}$ & $\begin{array}{l}\text { buy shares in } \\
\text { other plants). }\end{array}$ & & & & & $\begin{array}{l}\text { co-ownership in the } \\
\text { plant. }\end{array}$ \\
\hline Channels & $\begin{array}{l}\text { Presentations for } \\
\text { stakeholders; fairs and } \\
\text { seminars. } \\
\text { Landowners contact the } \\
\text { company. }\end{array}$ & $\begin{array}{l}\text { Screens the } \\
\text { country for good } \\
\text { projects. } \\
\text { Landowners } \\
\text { contact the } \\
\text { company. }\end{array}$ & $\begin{array}{l}\text { Customers contact } \\
\text { the company based } \\
\text { on attention/ } \\
\text { reputation. }\end{array}$ & $\begin{array}{l}\text { Through the } \\
\text { parent company. }\end{array}$ & $\begin{array}{l}\text { Landowners } \\
\text { contact the } \\
\text { company. }\end{array}$ & $\begin{array}{l}\text { Landowners contact } \\
\text { the company. } \\
\text { The company } \\
\text { contact the land } \\
\text { owners }\end{array}$ & $\begin{array}{l}\text { Contacts potential } \\
\text { investors. } \\
\text { Previous } \\
\text { collaborators and } \\
\text { landowners contact } \\
\text { them. }\end{array}$ \\
\hline $\begin{array}{l}\text { Revenue } \\
\text { streams }\end{array}$ & $\begin{array}{l}\text { Selling shares } 16 / 32 \\
\text { before the plant is built. } \\
\text { The payment plan } \\
\text { includes a signing fee, } \\
\text { 5-6 payments } \\
\text { (following the turbine } \\
\text { supplier's payment } \\
\text { plant) and a final } \\
\text { payment when the plant } \\
\text { is operational. }\end{array}$ & $\begin{array}{l}\text { Selling shares in } \\
\text { plants. }\end{array}$ & $\begin{array}{l}\text { Payment for } \\
\text { projects in } \\
\text { different stages: } \\
\text { initial payment, } \\
\text { payments under } \\
\text { construction, a } \\
\text { larger sum at the } \\
\text { end and final } \\
\text { payment two years } \\
\text { later. }\end{array}$ & $\begin{array}{l}\text { Payment for } \\
\text { project (one } \\
\text { buyer). }\end{array}$ & $\begin{array}{l}\text { Selling shares in } \\
\text { plants. } \\
\text { Electricity sales } \\
\text { and 'green' } \\
\text { electricity } \\
\text { certificates. }\end{array}$ & $\begin{array}{l}\text { Development and } \\
\text { management of } \\
\text { plants; sales of } \\
\text { projects that are } \\
\text { ready for } \\
\text { construction } \\
\text { Electricity sales. }\end{array}$ & $\begin{array}{l}\text { Electricity sales. } \\
\text { Payment for projects } \\
\text { (varies from project } \\
\text { to project); sell } \\
\text { shares, which are } \\
\text { paid in different } \\
\text { stages: signing fee } \\
\text { and additional } \\
\text { payments linked to } \\
\text { when they pay the } \\
\text { subcontractors. }\end{array}$ \\
\hline $\begin{array}{l}\text { Key } \\
\text { activities }\end{array}$ & $\begin{array}{l}\text { Screening of site, plant } \\
\text { design, land owner } \\
\text { agreements, EIA, wind } \\
\text { measurements, } \\
\text { calculations, sales, } \\
\text { construction, plant } \\
\text { management and } \\
\text { administration. }\end{array}$ & $\begin{array}{l}\text { Market research, } \\
\text { screening, land } \\
\text { contracts and } \\
\text { lease agreements, } \\
\text { pre-planning, } \\
\text { permit } \\
\text { application, } \\
\text { measurements and } \\
\text { inventories, } \\
\text { consultation, } \\
\text { construction. }\end{array}$ & $\begin{array}{l}\text { Consultation, plant } \\
\text { design, } \\
\text { construction and } \\
\text { plant management. } \\
\text { Problem solving. }\end{array}$ & $\begin{array}{l}\text { Wind } \\
\text { measurements, } \\
\text { permit } \\
\text { application } \\
\text { consultation, } \\
\text { coordination of } \\
\text { construction } \\
\text { companies and } \\
\text { plant operation. }\end{array}$ & $\begin{array}{l}\text { Electricity } \\
\text { production. } \\
\text { Design and } \\
\text { management of } \\
\text { wind power } \\
\text { plants, including } \\
\text { e.g. wind } \\
\text { measurements, } \\
\text { EIA and land } \\
\text { owner } \\
\text { agreements. }\end{array}$ & $\begin{array}{l}\text { Lease contracts, } \\
\text { wind measurements, } \\
\text { permit applications, } \\
\text { park design, } \\
\text { procurement, } \\
\text { financing, plant } \\
\text { management and } \\
\text { operation and sales } \\
\text { of already } \\
\text { operational plats. }\end{array}$ & $\begin{array}{l}\text { EIA, calculations } \\
\text { and wind } \\
\text { measurements, } \\
\text { procurement of } \\
\text { subcontractors, land } \\
\text { owner agreements, } \\
\text { infrastructure check- } \\
\text { ups). }\end{array}$ \\
\hline $\begin{array}{l}\text { Key } \\
\text { resources }\end{array}$ & $\begin{array}{l}\text { Technology/contact } \\
\text { with turbine } \\
\text { manufacturer (to take } \\
\text { advantage of updates). } \\
\text { Expertise in all areas. }\end{array}$ & $\begin{array}{l}\text { Experience (track } \\
\text { record and } \\
\text { expertise). }\end{array}$ & $\begin{array}{l}\text { Experience } \\
\text { Ability to get ideas } \\
\text { through at } \\
\text { different levels. }\end{array}$ & $\begin{array}{l}\text { Two strong } \\
\text { owners. } \\
\text { Competence to } \\
\text { run complex } \\
\text { projects. }\end{array}$ & $\begin{array}{l}\text { Experience. } \\
\text { Large number of } \\
\text { projects in } \\
\text { several countries }\end{array}$ & $\begin{array}{l}\text { Website: } \\
\text { Extensive } \\
\text { experience in wind } \\
\text { power development. }\end{array}$ & $\begin{array}{l}\text { Experience and } \\
\text { knowledge. } \\
\text { Capital to buy the } \\
\text { latest machines. }\end{array}$ \\
\hline
\end{tabular}




\begin{tabular}{|c|c|c|c|c|c|c|c|}
\hline & $\begin{array}{l}\text { A portfolio of wind } \\
\text { power projects. }\end{array}$ & $\begin{array}{l}\text { Own team that } \\
\text { manages } \\
\text { operations. }\end{array}$ & $\begin{array}{l}\text { Ability to make } \\
\text { investors feel safe. }\end{array}$ & Capital & $\begin{array}{l}\text { to evaluate and } \\
\text { invest in. }\end{array}$ & $\begin{array}{l}\text { Effective } \\
\text { management model. } \\
\text { Monitoring system } \\
\text { for operation and } \\
\text { maintenance. }\end{array}$ & $\begin{array}{l}\text { Certification (quality } \\
\text { and work } \\
\text { environment). } \\
\text { Checklists. }\end{array}$ \\
\hline $\begin{array}{l}\text { Key } \\
\text { partnerships }\end{array}$ & $\begin{array}{l}\text { Turbine supplier, } \\
\text { impact assessment } \\
\text { company }\end{array}$ & $\begin{array}{l}\text { Local contractors, } \\
\text { turbine supplier } \\
\text { (procured per } \\
\text { project) }\end{array}$ & $\begin{array}{l}\text { Consultants (wind } \\
\text { measurements), } \\
\text { financiers } \\
\text { (customer), } \\
\text { suppliers, various } \\
\text { subcontractors, } \\
\text { landowners }\end{array}$ & $\begin{array}{l}\text { EIA consultant, } \\
\text { subcontractors }\end{array}$ & $\begin{array}{l}\text { Turbine supplier, } \\
\text { the municipality, } \\
\text { local consultants, } \\
\text { local expertise }\end{array}$ & $\begin{array}{l}\text { Turbine suppliers } \\
\text { (framework } \\
\text { agreement) }\end{array}$ & $\begin{array}{l}\text { Consultants, } \\
\text { subcontractors, wind } \\
\text { turbine supplier, } \\
\text { lawyers, third-party } \\
\text { inspectors }\end{array}$ \\
\hline $\begin{array}{l}\text { Cost } \\
\text { structure }\end{array}$ & $\begin{array}{l}\text { Wind turbines, impact } \\
\text { assessments, grid } \\
\text { connection, wind } \\
\text { measurements, service, } \\
\text { lease costs, } \\
\text { infrastructure (roads and } \\
\text { foundations), sound } \\
\text { measurements after } \\
\text { construction, insurance } \\
\text { for dismantling }\end{array}$ & N.a. & $\begin{array}{l}\text { Infrastructure } \\
\text { (road, } \\
\text { foundations), } \\
\text { connection to the } \\
\text { grid, impact } \\
\text { assessment, } \\
\text { investments to get } \\
\text { new customers } \\
\text { (e.g. trips to } \\
\text { China) }\end{array}$ & $\begin{array}{l}\text { Large upfront } \\
\text { development } \\
\text { costs (to get } \\
\text { permit) }\end{array}$ & $\begin{array}{l}\text { Wind turbines, } \\
\text { infrastructure } \\
\text { subcontractors, } \\
\text { service } \\
\text { agreement }\end{array}$ & $\begin{array}{l}\text { Wind } \\
\text { measurements, } \\
\text { permitting, interest } \\
\text { on loans }\end{array}$ & $\begin{array}{l}\text { Wind turbines, roads, } \\
\text { connection to the } \\
\text { grid, "site cost" (e.g. } \\
\text { environmental } \\
\text { permit), } \\
\text { service/operation } \\
\text { contract, insurance, } \\
\text { consultants }\end{array}$ \\
\hline
\end{tabular}


Table B2. Solar intermediaries' business models

\begin{tabular}{|c|c|c|c|c|c|c|c|}
\hline & Solar A & Solar B ny & Solar C ny & Solar D ny & Solar E ny & Solar F ny & Solar G ny \\
\hline $\begin{array}{l}\text { Value } \\
\text { proposition }\end{array}$ & $\begin{array}{l}\text { Consultancy } \\
\text { (procurement } \\
\text { tenders) }\end{array}$ & $\begin{array}{l}\text { Consultancy with } \\
\text { innovative niche } \\
\text { product (special type of } \\
\text { panels) }\end{array}$ & $\begin{array}{l}\text { Turnkey } \\
\text { solutions; } \\
\text { monitoring; } \\
\text { panel design }\end{array}$ & $\begin{array}{l}\text { Turnkey solutions; } \\
\text { "no cheating" }\end{array}$ & $\begin{array}{l}\text { Turnkey solutions; } \\
\text { carefully evaluated } \\
\text { technology }\end{array}$ & $\begin{array}{l}\text { Wholesale } \\
\text { (premium } \\
\text { panels); } \\
\text { calculations } \\
\text { (dimensioning) }\end{array}$ & $\begin{array}{l}\text { Turnkey solutions; } \\
\text { service; maintenance }\end{array}$ \\
\hline $\begin{array}{l}\text { Customer } \\
\text { segments }\end{array}$ & $\begin{array}{l}\text { Private housing } \\
\text { companies; } \\
\text { municipalities }\end{array}$ & $\begin{array}{l}\text { Larger companies; } \\
\text { municipalities }\end{array}$ & $\begin{array}{l}\text { Households, } \\
\text { farmers; } \\
\text { associations; } \\
\text { companies; } \\
\text { municipalities }\end{array}$ & $\begin{array}{l}\text { Households, } \\
\text { farmers; private } \\
\text { housing } \\
\text { companies; } \\
\text { municipalities }\end{array}$ & Companies & $\begin{array}{l}\text { Installers } \\
\text { (electricians, } \\
\text { builders, } \\
\text { specialized solar } \\
\text { companies) }\end{array}$ & Public organizations \\
\hline $\begin{array}{l}\text { Customer } \\
\text { relationships }\end{array}$ & $\begin{array}{l}\text { Customers through } \\
\text { recommendations } \\
\text { and calls from } \\
\text { customers. } \\
\text { Recurring } \\
\text { customers }\end{array}$ & N.a. & $\begin{array}{l}\text { Monitoring, } \\
\text { automatic } \\
\text { services }\end{array}$ & $\begin{array}{l}\text { Customers need to } \\
\text { be informed; } \\
\text { automatic services }\end{array}$ & N.a. & $\begin{array}{l}\text { Direct } \\
\text { (calculations, } \\
\text { support, } \\
\text { education) }\end{array}$ & $\begin{array}{l}\text { Procurement, i.e. } \\
\text { objective, non-loyal } \\
\text { customers }\end{array}$ \\
\hline Channels & Customer; network & $\begin{array}{l}\text { Through contacts, } \\
\text { architects etc., emails to } \\
\text { installation companies }\end{array}$ & $\begin{array}{l}\text { Web site, } \\
\text { lectures }\end{array}$ & $\begin{array}{l}\text { Number of } \\
\text { previous plants; } \\
\text { collaboration with } \\
\text { regional energy } \\
\text { company; skeleton } \\
\text { agreement with } \\
\text { housing company }\end{array}$ & $\begin{array}{l}\text { Direct contact; } \\
\text { reputation from } \\
\text { previous business; } \\
\text { demonstration } \\
\text { plant, courses }\end{array}$ & $\begin{array}{l}\text { Customer; own } \\
\text { contact; industry } \\
\text { association }\end{array}$ & $\begin{array}{l}\text { Tendering process; } \\
\text { recommendations }\end{array}$ \\
\hline $\begin{array}{l}\text { Revenue } \\
\text { streams }\end{array}$ & Consultancy hours & $\begin{array}{l}\text { Price covers the cost of } \\
\text { the product payment for } \\
\text { the product (tradable } \\
\text { green certificate meter) } \\
\text { and the work around it. }\end{array}$ & $\begin{array}{l}\text { Material plus } \\
\text { hours. }\end{array}$ & $\begin{array}{l}\text { Fixed price, but } \\
\text { with extra charge } \\
\text { for extras. }\end{array}$ & $\begin{array}{l}\text { Maximum price, } \\
\text { but not fixed price. } \\
\text { Margin on } \\
\text { materials plus } \\
\text { work. No margin } \\
\text { on ACW. }\end{array}$ & $\begin{array}{l}\text { Panel plus } \\
\text { information } \\
\text { (included in } \\
\text { price) }\end{array}$ & $\begin{array}{l}\text { Competitive pricing } \\
\text { (tenders); projects } \\
\text { that require } \\
\text { additional and } \\
\text { correctional work } \\
\text { (ACW) }\end{array}$ \\
\hline
\end{tabular}




\begin{tabular}{|c|c|c|c|c|c|c|c|}
\hline $\begin{array}{l}\text { Key } \\
\text { activities }\end{array}$ & $\begin{array}{l}\text { Consultant work. } \\
\text { Mostly internal. }\end{array}$ & $\begin{array}{l}\text { Testing, project } \\
\text { development }\end{array}$ & $\begin{array}{l}\text { Advice, project } \\
\text { development, } \\
\text { installation etc. } \\
\text { Mostly in- } \\
\text { house. }\end{array}$ & $\begin{array}{l}\text { Everything, from } \\
\text { purchasing and } \\
\text { storing holding to } \\
\text { maintenance and } \\
\text { subsidy } \\
\text { applications. }\end{array}$ & $\begin{array}{l}\text { Project } \\
\text { development, } \\
\text { testing, installation, } \\
\text { education. }\end{array}$ & $\begin{array}{l}\text { Calculations, } \\
\text { dimensioning. }\end{array}$ & $\begin{array}{l}\text { Find discrepancies in } \\
\text { tenders that can } \\
\text { result in ACW. }\end{array}$ \\
\hline $\begin{array}{l}\text { Key } \\
\text { resources }\end{array}$ & $\begin{array}{l}\text { Knowledge, broad } \\
\text { competence, } \\
\text { network. }\end{array}$ & $\begin{array}{l}\text { Knowledge about } \\
\text { technology and } \\
\text { installation. }\end{array}$ & $\begin{array}{l}\text { Knowledge; } \\
\text { three different } \\
\text { technologies }\end{array}$ & $\begin{array}{l}\text { Knowledge; broad } \\
\text { competence; } \\
\text { coordination of } \\
\text { other parties; } \\
\text { customer } \\
\text { relationship }\end{array}$ & $\begin{array}{l}\text { Demonstration } \\
\text { plant; knowledge } \\
\text { from testing; model } \\
\text { to calculate } \\
\text { profitability.; } \\
\text { knowledge about } \\
\text { regulations etc. }\end{array}$ & $\begin{array}{l}\text { Knowledge of } \\
\text { product and } \\
\text { suppliers; } \\
\text { customer } \\
\text { relationships }\end{array}$ & $\begin{array}{l}\text { Legal competence; } \\
\text { reference plants }\end{array}$ \\
\hline $\begin{array}{l}\text { Key } \\
\text { partnerships }\end{array}$ & Panel suppliers & $\begin{array}{l}\text { Wholesaler/retailer; } \\
\text { installers; construction } \\
\text { companies }\end{array}$ & $\begin{array}{l}\text { Panel suppliers } \\
\text { (3); installers; } \\
\text { consultants. }\end{array}$ & $\begin{array}{l}\text { Panel supplier (1); } \\
\text { competent } \\
\text { electricians. }\end{array}$ & $\begin{array}{l}\text { Panel suppliers ( } 2) \text {; } \\
\text { suppliers of other } \\
\text { components. }\end{array}$ & $\begin{array}{l}\text { Panel suppliers } \\
\text { (2-3); installers; } \\
\text { transport } \\
\text { companies; bank. }\end{array}$ & $\begin{array}{l}\text { Wholesaler } \\
\text { (dimensioning) }\end{array}$ \\
\hline $\begin{array}{l}\text { Cost } \\
\text { structure }\end{array}$ & Personnel & $\begin{array}{l}\text { Panels; time; installation } \\
\text { equipment }\end{array}$ & $\begin{array}{l}\text { Panels; } \\
\text { installation } \\
\text { equipment }\end{array}$ & $\begin{array}{l}\text { Panels and other } \\
\text { components; large } \\
\text { volume purchase }\end{array}$ & $\begin{array}{l}\text { Panels; time; } \\
\text { development costs }\end{array}$ & $\begin{array}{l}\text { Interest on loans } \\
\text { (large volume } \\
\text { purchases); } \\
\text { panels and } \\
\text { materials. }\end{array}$ & $\begin{array}{l}\text { Safety equipment; } \\
\text { panels (per project) }\end{array}$ \\
\hline
\end{tabular}

